Check for updates

Cite this: RSC Adv., 2019, 9, 13444

\title{
Polydopamine functionalized hydrogel beads as magnetically separable antibacterial materials $\dagger$
}

\begin{abstract}
Ishita Matai, (D) *ab Mayank Garg, (D) ab Kajal Rana and Suman Singh (D) ab
In the present study, magnetically separable hydrogel beads of ionically cross-linked alginate were functionalized with polydopamine (PDA). The rationale behind this was to enhance the structural stability and antibacterial profile of $\mathrm{PDA} / \mathrm{Alg} / \mathrm{Fe}_{3} \mathrm{O}_{4}$ beads (K3). Incorporation of superparamagnetic magnetite $\left(\mathrm{Fe}_{3} \mathrm{O}_{4}\right)$ nanoparticles endowed the hydrogel beads with magnetism. X-ray diffraction (XRD) analysis revealed the successful formation of pure $\mathrm{Alg} / \mathrm{Fe}_{3} \mathrm{O}_{4}$ nanoparticles having an inverse spinel structure. Vibrating sample magnetometry (VSM) confirmed their superparamagnetic behaviour with $M_{\mathrm{s}}$ values of 36.18 and $30.46 \mathrm{emu} \mathrm{g}^{-1}$ at 5 and $300 \mathrm{~K}$, respectively. High resolution-transmission electron microscopy (HR-TEM) images showed alginate capping and the size of the $\mathrm{Alg} / \mathrm{Fe}_{3} \mathrm{O}_{4}$ nanoparticles ( $\left.8 \mathrm{~nm}\right)$. The successful deposition of PDA granules on the $\mathrm{K} 3$ bead surface was verified by field emission-scanning electron microscopy (FE-SEM). The PDA functionalization was further justified by VSM, XRD and Fouriertransform infrared spectroscopy (FT-IR). During swelling experiments, K3 beads displayed appreciable structural stability compared to bare/non-functionalized beads. Wettability studies revealed K3 beads to be hydrophilic with a contact angle of $\sim 55^{\circ}$. Rheological parameters including storage modulus $\left(\mathrm{G}^{\prime}\right)$ and shear viscosity of K3 increased upon PDA functionalization. During antibacterial tests, K3 strongly inhibited E. coli, S. typhi, S. aureus and L. monocytogenes in a concentration and time dependent manner. Fluorescence staining experiments showed that $\mathrm{K} 3$ could greatly alter the bacterial membrane integrity. Reusability experiments with $\mathrm{K} 3$ beads substantiated their effective broad-spectrum antibacterial performance for three consecutive cycles.
\end{abstract}

Received 24th January 2019 Accepted 18th April 2019

DOI: $10.1039 / c 9 r a 00623 k$

rsc.li/rsc-advances

\section{Introduction}

Access to clean, fresh water is a great challenge afflicting the world in particular the developing countries. Problems with water are continuously on the rise, with water scarcity intensifying due to climate changes and water pollution. ${ }^{1}$ At present, an estimated 3.6 billion people (nearly half of the global population) live in potentially water-scarce regions and this is expected to reach $4.8-5.7$ billion by $2050 .{ }^{2}$ Deterioration of water quality has further aggravated the problem. Amongst the various water contaminants, pathogenic microorganisms which either exist as biofilms on water carrying pipelines or in planktonic (free) form are the main causative agents of waterborne infections. ${ }^{3-8}$ Currently, the water treatment processes for removal of microorganisms rely on addition of chlorine, bromine, ozone or UV treatment. ${ }^{9}$ Research indicates that pathogens have acquired resistance to disinfection by chlorination. ${ }^{10,11}$ In addition, the disinfectant by-products are

${ }^{a}$ Central Scientific Instruments Organization (CSIR-CSIO), Chandigarh-160030, India. E-mail: ishitamatai@csio.res.in; ishitamatai11@gmail.com; Tel: +91-172-2672281

${ }^{b}$ Academy of Scientific and Innovative Research, CSIR-CSIO, Chandigarh-160030, India

$\dagger$ Electronic supplementary information (ESI) available. See DOI: $10.1039 / \mathrm{c} 9 \mathrm{ra} 00623 \mathrm{k}$ detrimental to health and ozone or UV treatments are expensive.

Development of cost-effective and eco-friendly materials which can interact and inhibit such pathogenic microbes without affecting the water quality are certainly valuable. Combination of the knowledge of chemistry, nanotechnology and biology can innovate strategies to formulate effective materials to obtain clean water. Iron oxide nanoparticles, owing to their biocompatibility, cost-effective synthesis, ease of surface engineering and magnetism have proven suitable for biomedical and water purification applications. ${ }^{12,13}$ Superparamagnetic iron oxide nanoparticles (SPIONs), including magnetite $\left(\mathrm{Fe}_{3} \mathrm{O}_{4}\right)$ and maghemite $\left(\gamma-\mathrm{Fe}_{2} \mathrm{O}_{3}\right)$ are well-recognized for their excellent ability as nanoadsorbents either in free form or as composites for organic pollutants and heavy metals for water purification. ${ }^{13-15}$ Polymeric hydrogels encapsulating such magnetic iron oxide nanoparticles either bare or surface modified can serve as a versatile platform to remove microbes and ions in waters. ${ }^{16}$ After action, these hydrogels can be separated with an external magnet giving way to a fast and effective approach.

Amongst various sources for hydrogel preparation, naturally occurring sodium alginate is widely known. Basically, alginate is a linear polysaccharide used extensively in food, cosmetics, 
pharmaceutical and biomedical industries owing to its biocompatibility and gel-forming tendencies in presence of divalent cations. ${ }^{17-19}$ It is composed of consecutive units of (1-4) linked $\alpha$-L-guluronate (G) and $\beta$-D-mannuronate $(M)$ residues followed by alternating segments of $\mathrm{M}-\mathrm{G}$ blocks. ${ }^{17,20}$ Divalent cations such as calcium, barium and strontium can ionically complex to $\mathrm{G}$ blocks of two alginate polymers, forming the popular "egg-box structure". ${ }^{21,22}$ Use of $\mathrm{Ca}^{2+}$ to prepare alginate hydrogels and microbeads for cell or protein encapsulation and drug delivery has been reported. ${ }^{22-27}$ Thaya et al. demonstrated antibacterial activity of $\mathrm{Ca}^{2+}$ cross-linked alginate/chitosan microspheres. ${ }^{28}$ El-Aassar and Mo tested antibacterial activity of alginate microbeads containing silver nanoparticles (AgNPs). ${ }^{29}$ Zahran et al. modified surface of cotton fabric with AgNPs-alginate composite and evaluated their antibacterial activity. ${ }^{30}$ Madzovska-Malagurski et al. synthesized bioactive $\mathrm{Cu}$ alginate hydrogels and showed their bactericidal activity against Escherichia coli and Staphylococcus aureus. ${ }^{31}$ Nevertheless, the long-term toxic effects induced by leached metal ions (silver and copper) questions their utility for water treatment.

Recently, dopamine (3,4-dihydroxyphenethylamine, DA) a small molecule analog of catechol and amine rich proteins of marine mussels is being much investigated. ${ }^{32}$ Under mild alkaline $\mathrm{pH}$ and in presence of oxygen, DA self-polymerizes to form polydopamine (PDA) layers on virtually any surface. Versatile adhesion capability, catalytic, antimicrobial and antifouling properties of PDA renders it as a suitable functionalization material. ${ }^{33-38}$ Also, like other natural adhesive proteins PDA exhibits good biocompatibility and low-toxicity to the environment. ${ }^{39}$ Hence, use of PDA as a functionalization material can serve as a facile and ecofriendly strategy to provide stability and antibacterial competence.

In the present work, PDA functionalized magnetic hydrogel beads have been prepared using a step-wise strategy. Alginate was used as base hydrogel material to form beads by ionic cross-linking with divalent $\mathrm{Ca}$. To make beads magnetic, alginate stabilized $\mathrm{Fe}_{3} \mathrm{O}_{4}$ nanoparticles were entrapped inside the alginate porous network. Thereafter, immersion of Alg/ $\mathrm{Fe}_{3} \mathrm{O}_{4}$ beads in mild alkaline solution of DA resulted in surface functionalization with PDA. Herein, PDA exhibits dual functionality, (i) provides structural stability to alginate/ $\mathrm{Fe}_{3} \mathrm{O}_{4}$ beads by forming a uniform adherent coating and (ii) imparts antibacterial potential. As a proof of concept, as-synthesized $\mathrm{PDA} / \mathrm{Alg} / \mathrm{Fe}_{3} \mathrm{O}_{4}$ beads (K3) were evaluated for their stability under different $\mathrm{pH}$ conditions. Further, they were then assessed for their antibacterial efficacy against common water pathogens: Gram negative Escherichia coli (E. coli) and Salmonella typhimurium (S. typhi) and Gram positive Staphylococcus aureus (S. aureus) and Listeria monocytogenes (L. monocytogenes), respectively as model organisms. The $\mathrm{K} 3$ beads exhibited enhanced antibacterial activity against all the four bacterial strains compared to bare alginate (K1) and unmodified $\mathrm{Alg} / \mathrm{Fe}_{3} \mathrm{O}_{4}$ beads (K2). Hence, $\mathrm{K} 3$ beads formulated with inherently biocompatible materials with antibacterial and magnetism properties are potential candidates for use in bacterial removal.

\section{Experimental section}

\subsection{Chemicals, bacterial strains and growth media}

All the chemicals were of reagent grade and used without purification. Sodium alginate (Alg), aqueous ammonia (25\% $\mathrm{NH}_{4} \mathrm{OH}$ ) and dopamine hydrochloride were purchased from Sigma-Aldrich (India). Iron(II) chloride tetrahydrate $\left(\mathrm{FeCl}_{2}\right.$ $\left.\cdot 4 \mathrm{H}_{2} \mathrm{O}\right)$, Iron(III) chloride hexahydrate $\left(\mathrm{FeCl}_{3} \cdot 6 \mathrm{H}_{2} \mathrm{O}\right)$ and calcium chloride, anhydrous were procured from Alfa Aesar and HiMedia (India), respectively. Gram negative E. coli (MTCC 1302) and S. typhi (MTCC 98) and Gram positive S. aureus (MTCC 96) and L. monocytogenes (MTCC 657) were obtained from CSIR-Institute of Microbial Technology (IMTECH), India. Bacterial growth medium-nutrient broth (NB) medium, was purchased from HiMedia (India). All the preparations were made in deionized (DI) water.

\subsection{Synthesis of Alg coated iron oxide nanoparticles (Alg/ $\left.\mathrm{Fe}_{3} \mathrm{O}_{4}\right)$}

Coated magnetite nanoparticles $\left(\mathrm{Fe}_{3} \mathrm{O}_{4}\right)$ were synthesized by coprecipitation method using $\mathrm{Fe}^{3+} / \mathrm{Fe}^{2+}$ in molar ratio of $2: 1$ with slight modification. ${ }^{40}$ Iron(II) chloride (1.5 g) and iron(III) chloride $\left(3 \mathrm{~g}\right.$ ) were dissolved in $50 \mathrm{~mL}$ DI water @ $450 \mathrm{rpm}$ at $80{ }^{\circ} \mathrm{C}$ for $1 \mathrm{~h}$ under nitrogen $\left(\mathrm{N}_{2}\right)$ atmosphere. For coating, $0.8 \mathrm{wt} \%$ sodium alginate was added to the iron solution at $80{ }^{\circ} \mathrm{C}$ and kept for $2 \mathrm{~h}$. Then, $10 \mathrm{~mL}$ of $25 \mathrm{wt} \% \mathrm{NH}_{4} \mathrm{OH}$ solution was added into the above solution very slowly. Upon addition, the color of solution changed immediately from orange to black. The obtained black precipitates were extracted using strong neodymium magnet $(\mathrm{NdFeB})$ and filtered using Whatman ${ }^{\mathrm{TM}}$ filter paper $(125 \mathrm{~mm})$. The precipitates were then washed twice with DI water (to remove chloride ions) and absolute ethanol (to remove excess $\mathrm{Alg}$ ). $\mathrm{Alg} / \mathrm{Fe}_{3} \mathrm{O}_{4}$ nanoparticles were finally obtained after vacuum drying at $80{ }^{\circ} \mathrm{C}$ for $24 \mathrm{~h}$ and stored at room temperature.

\subsection{Preparation of Alg hydrogel (Alg) beads (K1)}

$1 \mathrm{~g}$ of sodium alginate powder was dissolved in $50 \mathrm{~mL}$ DI water under stirring conditions at $50{ }^{\circ} \mathrm{C}$ to obtain transparent, viscous Alg hydrogel solution. To formulate Alg hydrogel as spherical beads, this solution was added dropwise using $1 \mathrm{~mL}$ pipette into $50 \mathrm{~mL}$ of $0.2 \mathrm{M} \mathrm{CaCl}_{2}$ solution (a) $100 \mathrm{rpm}$ to instantaneously form beads. The beads were left for $1 \mathrm{~h}$ in the $\mathrm{CaCl}_{2}$ solution to ensure complete crosslinking. Formation of beads was due to electrostatic interactions between guluronate blocks of alginate chain and $\mathrm{Ca}^{2+}$ ions. ${ }^{27}$ The beads were then filtered, collected and washed twice with DI water.

\subsection{Preparation of $\mathrm{Alg} / \mathrm{iron}$ oxide hydrogel $\left(\mathrm{Alg} / \mathrm{Fe}_{3} \mathrm{O}_{4}\right)$ beads} (K2)

$\mathrm{Alg} / \mathrm{Fe}_{3} \mathrm{O}_{4}$ nanoparticles prepared in 2.2 were entrapped in the porous structure of Alg beads. For this, $250 \mathrm{mg} \mathrm{Alg} /$ $\mathrm{Fe}_{3} \mathrm{O}_{4}$ nanoparticles were added to $50 \mathrm{~mL} \mathrm{Alg}$ hydrogel solution (prepared in 2.3) @ $450 \mathrm{rpm}$ at $50{ }^{\circ} \mathrm{C}$ for $4 \mathrm{~h}$. 
Thereafter, this solution was added drop-wise into $50 \mathrm{~mL}$ of $0.2 \mathrm{M} \mathrm{CaCl}_{2}$ for $1 \mathrm{~h}$. Uniform spherical beads of $\mathrm{Alg} / \mathrm{Fe}_{3} \mathrm{O}_{4}$ were collected using external $\mathrm{NdFeB}$ magnet and washed twice with DI water.

\subsection{Preparation of PDA functionalized magnetic hydrogel (PDA/Alg/ $/ \mathrm{Fe}_{3} \mathrm{O}_{4}$ ) beads (K3)}

First, $10 \mathrm{mg} \mathrm{mL}^{-1}$ of dopamine hydrochloride was dissolved in $30 \mathrm{~mL}$ of $0.1 \mathrm{M}$ Tris Cl buffer ( $\mathrm{pH}$ 8.0) under mild stirring at room temperature. For surface functionalization, $1 \mathrm{~g}$ of $\mathrm{K} 2$ beads were dropped in above solution and stirred @ $200 \mathrm{rpm}$ for $24 \mathrm{~h}$ at room temperature in dark. Change in color of beads from dark brown to black was observed after functionalization of PDA on $\mathrm{Alg} / \mathrm{Fe}_{3} \mathrm{O}_{4}$ bead surface. Functionalized beads were then filtered, collected and washed with DI water. Subsequently, the beads were stored at $-20{ }^{\circ} \mathrm{C}$ after freeze-drying.

\subsection{Characterization}

X-Ray Diffraction (XRD) patterns were acquired using a Model D8 Advance (M/s Bruker AXS, Germany) X-ray diffractometer with monochromatic $\mathrm{Cu}-\mathrm{K} \alpha$ radiation $(\lambda=1.5406 \AA)$ in the range of $20^{\circ}-80^{\circ}(2 \theta)$ and a scan speed of $0.5^{\circ} \mathrm{min}^{-1}$. FourierTransform Infrared (FT-IR) spectra were recorded with PerkinElmer spectrometer in the range 4000-400 $\mathrm{cm}^{-1}$. The magnetic measurements (Magnetization versus field $(M-H)$ ) at 5 and $300 \mathrm{~K}$ were carried out using a 3 tesla cryogen free mini Vibrating Sample Magnetometer (VSM) with a pulse cryocooler (Cryogenics Ltd, UK). The zeta potential and hydrodynamic diameter of samples were estimated using Malvern Zetasizer (ZS90). For sample preparation, $0.5 \mathrm{mg} \mathrm{mL}^{-1}$ samples were dispersed in DI water by sonication for $5 \mathrm{~min}$. The morphology of $\mathrm{Alg} / \mathrm{Fe}_{3} \mathrm{O}_{4}$ nanoparticles was recorded by FE-SEM (Nova NanoSEM) at an accelerating voltage of $15 \mathrm{kV}$. Alg/ $/ \mathrm{Fe}_{3} \mathrm{O}_{4}$ nanoparticle powders were placed on double-sided carbon tape on $\mathrm{Al}$ stub and viewed under FE-SEM after gold sputtering. The elemental composition was observed from energy dispersive $\mathrm{X}$ ray spectroscopy (EDS) coupled with FE-SEM. For viewing the morphology and internal structure of functionalized magnetic beads, the freeze-dried beads were cross-sectioned using a sharp blade and placed on carbon tape and imaged. High resolution-transmission electron microscopy (HR-TEM) was used for studying the size and crystal structure of $\mathrm{Alg} / \mathrm{Fe}_{3} \mathrm{O}_{4}$ nanoparticles. For imaging, sample preparation included dispersion of $0.5 \mathrm{mg} \mathrm{mL} \mathrm{m}^{-1} \mathrm{Alg} / \mathrm{Fe}_{3} \mathrm{O}_{4}$ nanoparticles in DI water followed by sonication for $10 \mathrm{~min}$. The solution was then dropped on non-shining side of carbon coated $\mathrm{Cu}$ grid, air dried and viewed under FEI Technai G2 TEM, operating at $200 \mathrm{kV}$. The lattice fringes, selected area electron diffraction (SAED) pattern and EDS spectra were also recorded using same instrument. Gatan Digital Micrograph software was used to obtain inverse fast Fourier transform (IFFT) images. For wettability studies, around $4 \mu \mathrm{L}$ of DI water was dropped onto freezedried beads surface and contact angles were measured using Drop Shape Analyzer DSA-100E (Kruss, Germany). Sessile drop method was employed for measurements.

\subsection{Swelling studies}

For swelling studies, $5 \mathrm{mg}$ of freeze-dried beads were immersed separately in $5 \mathrm{~mL}$ of sodium acetate buffer ( $\mathrm{pH} 5.5)$ and PBS (pH 7.4) buffers, respectively at room temperature for different time intervals $(3,6,9,1,24 \mathrm{~h}) .^{20}$ After incubation, the swollen beads were carefully removed and placed on a piece of tissue paper to remove excess water from surface of beads. Weight of beads was then measured using a weighing balance. Percent swelling was then calculated with the following formula:

$$
\% \text { Swelling }=\frac{S 2-S 1}{S 1} \times 100
$$

where, S1 is the initial weight of dried beads and S2 is the weight of beads after swelling.

\subsection{Rheological measurements}

The rheological properties of hydrogel beads were measured using a rotational rheometer (Bohlin rheometer CVO 100, Malvern Instruments Ltd.). A $20 \mathrm{~mm}$ parallel plate was used for experiments. A height gap of $500 \mu \mathrm{m}$ between the plates was optimized depending on hydrogel bead thickness. 2-3 dried beads were dipped in $10 \mathrm{~mL}$ DI water for $\sim 1 \mathrm{~h}$ and carefully placed on plate. Two experiments were performed at $25{ }^{\circ} \mathrm{C}$ to explore their rheological behavior, (a) frequency sweep test from $0.1-10 \mathrm{~Hz}$ at a constant stain of $0.1 \%$ and (b) shear viscometry test with shear rate varying from $0.1-100 \mathrm{~s}^{-1}$.

\subsection{Antibacterial activity of K3 beads}

The antibacterial capability of functionalized magnetic beads was evaluated against four bacterial strains namely $E$. coli, $S$. typhi, S. aureus, and L. monocytogenes using different assays. For bacterial inoculation, $1 \%(\mathrm{v} / \mathrm{v})$ bacteria was cultured overnight in $\mathrm{NB}$ growth medium at $180 \mathrm{rpm}$ at $37{ }^{\circ} \mathrm{C}$ in a bacterial incubator.

2.9.1 Concentration dependent bacterial inhibition. For performing antibacterial experiments, a fresh NB tube was inoculated with $1 \%(\mathrm{v} / \mathrm{v})$ bacteria for $5 \mathrm{~h}$ at $180 \mathrm{rpm}$ and $37^{\circ} \mathrm{C}$. Different concentrations of $\mathrm{K} 1, \mathrm{~K} 2$ and $\mathrm{K} 3$ beads $(2,4,8,12,16$, $20 \mathrm{mg}$ ) were added to test tubes containing $5 \mathrm{~mL} \mathrm{NB}$ medium and $1 \%(\mathrm{v} / \mathrm{v})$ bacteria. These were kept for incubation under shaking conditions @ $180 \mathrm{rpm}$ for $12 \mathrm{~h}$ at $37^{\circ} \mathrm{C}$. Tubes with only bacteria were considered as positive controls, while tubes having only NB medium and hydrogel beads were taken as negative controls. ${ }^{41}$ After $12 \mathrm{~h}$, the optical density (OD) of medium was estimated from absorbance values acquired using a UV-visible spectrophotometer (Lab India UV 3200) at $600 \mathrm{~nm}$. Absorbance of negative controls was subtracted from the sample absorbance and compared with the positive control to evaluate the antibacterial activity. The experiments were performed in triplicate.

2.9.2 Bacterial growth kinetics. For performing bacterial kinetics, K3 beads (12 mg) were exposed to NB medium ( $5 \mathrm{~mL}$ ) containing $1 \%(\mathrm{v} / \mathrm{v})$ bacteria ( $2 \mathrm{~h}$ grown culture) and kept for incubation for $0.5,1,3,6$, and $8 \mathrm{~h}$, respectively at $180 \mathrm{rpm}$ and $37{ }^{\circ} \mathrm{C}$. At stipulated time intervals, the OD of treated bacterial culture was measured at $600 \mathrm{~nm}$. The variation in absorbance at 
$600 \mathrm{~nm}$ of $\mathrm{K} 3$ treated bacteria was plotted as a function of time and compared with control bacteria.

2.9.3 Membrane integrity assay. For this assay, NB tubes (5 $\mathrm{mL}$ ) with $1 \%(\mathrm{v} / \mathrm{v})$ bacteria ( $2 \mathrm{~h}$ grown culture) were exposed to $\mathrm{K} 3$ beads $(12 \mathrm{mg})$ for $8 \mathrm{~h}$ under shaking conditions at $37^{\circ} \mathrm{C}$. NB tubes with untreated bacteria were also kept as control. After K3 beads exposure, $1.5 \mathrm{~mL}$ bacterial culture was centrifuged at $10000 \mathrm{rpm}$ for $5 \mathrm{~min}$ at $4{ }^{\circ} \mathrm{C}$. The supernatant was carefully discarded and the obtained pellet was washed twice with PBS (24.32 mM). The cell pellet was then resuspended again in $1 \mathrm{~mL}$ PBS containing fluorescent propidium iodide (PI) dye (final concentration $2 \mu \mathrm{g} \mathrm{mL} \mathrm{m}^{-1}$ ). The samples were left for incubation in dark for $10 \mathrm{~min}$ at room temperature. ${ }^{42}$ Thereafter, the fluorescence spectra were acquired using multi-mode plate reader (Molecular Devices-SpectraMax i3x, USA) at excitation wavelength $535 \mathrm{~nm}$ and emission wavelength $625 \mathrm{~nm}$.

2.9.4 Reusability experiments. In this assay, K3 beads ( 12 $\mathrm{mg}$ ) were added to NB tubes $(5 \mathrm{~mL})$ containing $1 \%(\mathrm{v} / \mathrm{v})$ bacteria and left for $12 \mathrm{~h}$ under shaking conditions at $37^{\circ} \mathrm{C}$. NB tubes with untreated bacteria were also kept as control. After $12 \mathrm{~h}$, OD at $600 \mathrm{~nm}$ of treated and control bacteria were recorded. This was considered as cycle 1 . Thereafter, the beads were carefully separated with the help of external magnet and thoroughly washed with PBS to remove any adherent dead bacteria. Subsequently, the beads were added to fresh $5 \mathrm{~mL} \mathrm{NB}$ medium tubes containing $1 \%(\mathrm{v} / \mathrm{v})$ bacteria and left for $12 \mathrm{~h}$ under shaking conditions at $37^{\circ} \mathrm{C}$. OD at $600 \mathrm{~nm}$ was recorded after $12 \mathrm{~h}$ (cycle 2 ). The beads were again washed with PBS and the entire process was repeated for 2 more times (cycle 3 and 4 ). ${ }^{43}$ The percent inhibition in bacteria was calculated using formula:

$$
\% \text { Inhibition }=\left[\frac{A_{\mathrm{c}}-A_{\mathrm{t}}}{A_{\mathrm{c}}}\right] \times 100
$$

where, $A_{\mathrm{c}}$ is the absorption value of control bacteria at $600 \mathrm{~nm}$, $A_{\mathrm{t}}$ is the absorption value of $\mathrm{K} 3$ treated bacteria at $600 \mathrm{~nm}$.

\section{Results and discussion}

In this study, PDA functionalised magnetic matrices in the form of beads have been prepared and assessed for their antibacterial activity. The entire methodology adopted for the preparation of $\mathrm{PDA} / \mathrm{Alg} / \mathrm{Fe}_{3} \mathrm{O}_{4}$ beads (K3) has been schematically depicted in Scheme 1.

\subsection{Characterization}

$\mathrm{Alg} / \mathrm{Fe}_{3} \mathrm{O}_{4}$ nanoparticles were characterized for their magnetic behavior, nanometer size, crystalline structure and purity. Visual demonstration of magnetic characteristics was done

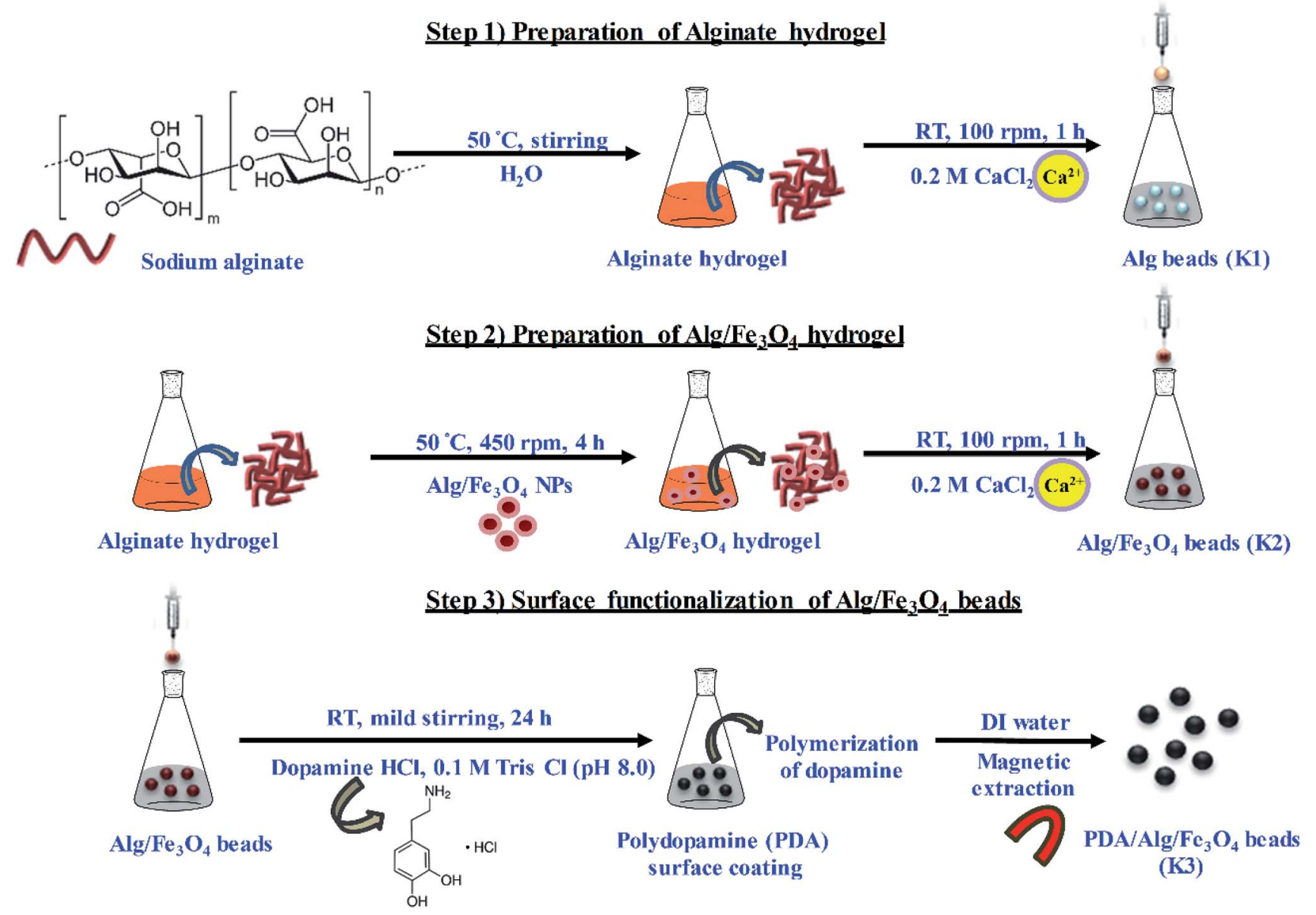

Scheme 1 Schematic depiction of step-wise preparation of functionalized PDA/Alg/ $/ \mathrm{Fe}_{3} \mathrm{O}_{4}(\mathrm{~K} 3)$ beads. 
using an external, strong NdFeB magnet. Fig. 1(a) clearly indicates strong affinity of the synthesized $\mathrm{Alg} / \mathrm{Fe}_{3} \mathrm{O}_{4}$ nanoparticles towards magnet. When the magnet was brought in the vicinity of the nanoparticles, they exhibited strong attraction. It is imperative for iron oxide nanoparticles to have strong magnetic attraction so that when they are entrapped inside the hydrogel beads, the beads also exhibit magnetic features to ensure their magnetic separation.

Next, the magnetic properties of the synthesized $\mathrm{Alg} / \mathrm{Fe}_{3} \mathrm{O}_{4}$ nanoparticles were experimentally measured by VSM. Fig. 1(b) shows the hysteresis loops as a function of the magnetic field at 5 and $300 \mathrm{~K}$. At $300 \mathrm{~K}$, the nanoparticles exhibited typical superparamagnetic behavior with no hysteresis. The saturation magnetization $\left(M_{\mathrm{s}}\right)$ was $30.46 \mathrm{emu} \mathrm{g}^{-1}$ which is significantly less than that of bulk magnetization $\left(M_{\mathrm{s}}=92 \mathrm{emu}^{-1}\right)$. This is due to the size effect and is in accordance with the previous reported literature. ${ }^{\mathbf{4 4 , 4 5}}$ Also, the remnant magnetization $\left(M_{\mathrm{r}}\right)$ and coercivity $\left(H_{\mathrm{c}}\right)$ values were close to zero. While at $5 \mathrm{~K}, \mathrm{Alg} / \mathrm{Fe}_{3} \mathrm{O}_{4}$ nanoparticles were superparamagnetic with $M_{\mathrm{S}}$ value $36.18 \mathrm{emu}$ $\mathrm{g}^{-1}$. The magnetic parameters calculated from the data are mentioned in Table 1.

Subsequently, the XRD spectrum was recorded and is shown in Fig. 1(c). The characteristic peaks of iron oxide NPs crystal having an inverse spinel structure appeared in the $2 \theta$ range $\left(30^{\circ}-40^{\circ}\right)$. From XRD study, the nanoparticles with higher Miller indices were observed at (311) plane. The diffraction peaks of (220), (311), (400), (422), (511), and (440) planes reflect the magnetite crystal with face-centered cubic phase (JCPDS Card
No. 19-0629). ${ }^{40,46}$ Absence of diffraction peaks of (210), (213) and (330) planes confirm absence of maghemite in sample. Employing Scherrer's equation, the average crystallite size was calculated from the broad diffraction peak corresponding to (311) plane to be around $8 \mathrm{~nm}$. The plausible explanation of small size of $\mathrm{Alg} / \mathrm{Fe}_{3} \mathrm{O}_{4}$ nanoparticles is the use of alginate as coating and stabilizing agent. ${ }^{47}$ XRD data also confirms that coating did not affect the phase of iron oxide. ${ }^{45}$

The formation of $\mathrm{Alg} / \mathrm{Fe}_{3} \mathrm{O}_{4}$ nanoparticles was further studied by the FT-IR analysis. As shown in Fig. 1(d), several peaks were observed indicating the presence of different functional groups in $\mathrm{Alg} / \mathrm{Fe}_{3} \mathrm{O}_{4}$ nanoparticles. The peaks at 3414 and $3200 \mathrm{~cm}^{-1}$ correspond to the $\mathrm{O}-\mathrm{H}$ bond vibrations. Further, the sharp peaks at 1395 and $1604 \mathrm{~cm}^{-1}$ are of the asymmetric and symmetric stretching vibrations of $-\mathrm{COO}^{-}$groups. Other peaks at 1023 and $1064 \mathrm{~cm}^{-1}$ can be credited to the structural peaks of alginate. ${ }^{20}$ The band at $580 \mathrm{~cm}^{-1}$ is due to stretching vibration of $\mathrm{Fe}-\mathrm{O}$ bond in the tetrahedral and octahedral sites. ${ }^{40,47}$ This ascertained the successful formation of $\mathrm{Alg} / \mathrm{Fe}_{3} \mathrm{O}_{4}$ nanoparticles.

The finely powdered $\mathrm{Alg} / \mathrm{Fe}_{3} \mathrm{O}_{4}$ nanoparticles were thereafter subjected to FE-SEM analysis for their morphology and shape features. Fig. 1(e) shows presence of uniform sized, spherical $\mathrm{Alg} / \mathrm{Fe}_{3} \mathrm{O}_{4}$ nanoparticles with a tendency to agglomerate. For more clearer observation, TEM analysis was performed. Fig. 2(a and $b$ ) shows the TEM images of $\mathrm{Alg} / \mathrm{Fe}_{3} \mathrm{O}_{4}$ nanoparticles at different magnifications. The alginate coating on the synthesized $\mathrm{Fe}_{3} \mathrm{O}_{4}$ nanoparticles was evident from the images (a)

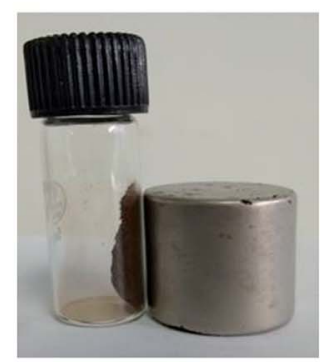

(b)

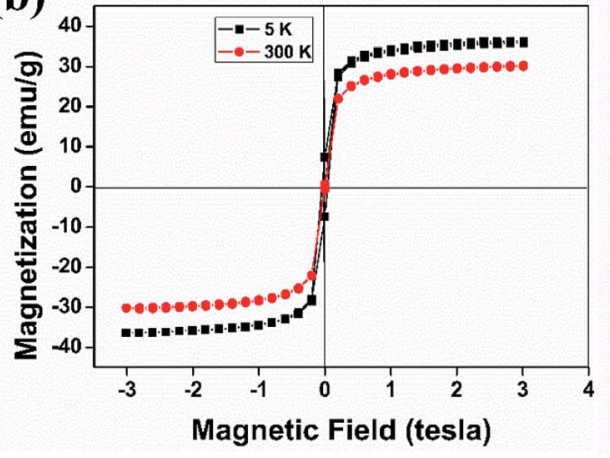

(c)

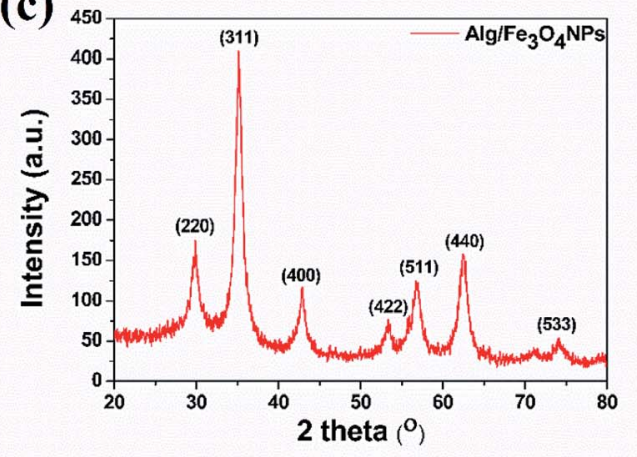

(d)

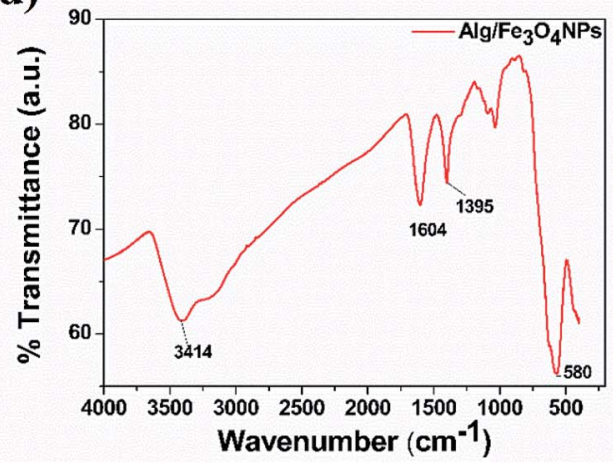

(e)

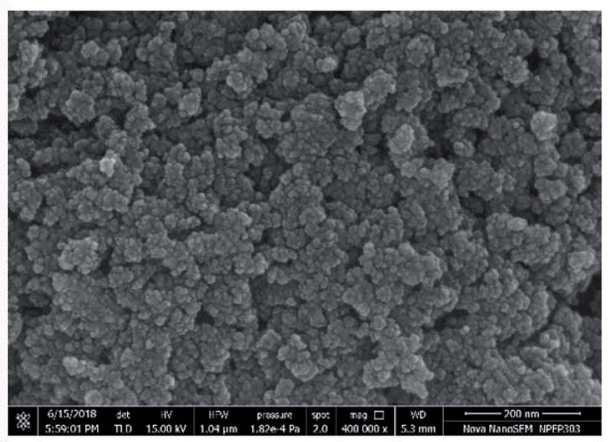

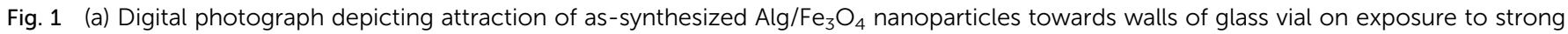
external NdFeB magnet, (b) VSM, (c) XRD, (d) FT-IR, and (e) FE-SEM data. 
Table 1 Magnetic parameters of $\mathrm{Alg} / \mathrm{Fe}_{3} \mathrm{O}_{4}$ nanoparticles

\begin{tabular}{|c|c|c|c|c|}
\hline Material & $\begin{array}{l}\text { Temperature } \\
\text { (K) }\end{array}$ & Saturation magnetization $\left(M_{\mathrm{s}}\right)\left(\mathrm{emu} \mathrm{g}^{-1}\right)$ & $\begin{array}{l}\text { Coercivity }\left(H_{\mathrm{s}}\right) \\
\text { (tesla) }\end{array}$ & Permanent magnetization $\left(M_{\mathrm{r}}\right)\left(\mathrm{emu} \mathrm{g}^{-1}\right)$ \\
\hline $\mathrm{Alg} / \mathrm{Fe}_{3} \mathrm{O}_{4}$ & 5 & 36.18 & 0.0425 & 7.275 \\
\hline
\end{tabular}

obtained (red arrows). The dark colored spots in the images correspond to the $\mathrm{Fe}_{3} \mathrm{O}_{4}$ nanoparticles with average particle size $8 \mathrm{~nm}$ (blue arrows). Presence of $\mathrm{Fe}, \mathrm{O}, \mathrm{C}$ elements in $\mathrm{Alg} / \mathrm{Fe}_{3} \mathrm{O}_{4}$ nanoparticle sample is clearly observed in the EDS spectra (Fig. S1 $\dagger$ ). The peaks pertaining to $\mathrm{Cu}$ element of the used TEM grid were also observed. The structure of $\mathrm{Alg} / \mathrm{Fe}_{3} \mathrm{O}_{4}$ nanoparticles was further investigated by HR-TEM. The lattice fringes of the image were separated and identified using Gatan software to create IFFT images by masking technique (Fig. 2(c) inset). An individual set of planes with lattice spacing (d) of $0.255 \mathrm{~nm}$ and $0.298 \mathrm{~nm}$, were observed which correspond to (220) and (311) characteristic planes of $\mathrm{Alg} / \mathrm{Fe}_{3} \mathrm{O}_{4}$ nanoparticles.
These results were in accordance with the XRD findings. Also, the SAED pattern displayed spotted diffraction rings confirming crystalline nature of nanoparticles (Fig. 2(d)).

The hydrodynamic size of as-synthesized $\mathrm{Alg} / \mathrm{Fe}_{3} \mathrm{O}_{4}$ nanoparticles was then recorded by DLS measurements and came out to be $141.9 \mathrm{~nm}$ (data not shown). The increased size in aqueous solution can probably be due to aggregation of $\mathrm{Alg} /$ $\mathrm{Fe}_{3} \mathrm{O}_{4}$ nanoparticles (as observed under TEM) and swelling of the alginate chains covering the nanoparticle surface..$^{48} \mathrm{Ma}$ et al. reported hydrodynamic diameter of SPIONs stabilized with alginate to be $\sim 193.8 \mathrm{~nm}^{49}$ Bedê et al. reported hydrodynamic diameter of $\mathrm{Fe}_{3} \mathrm{O}_{4}$ encapsulated in alginate/chitosan matrix to
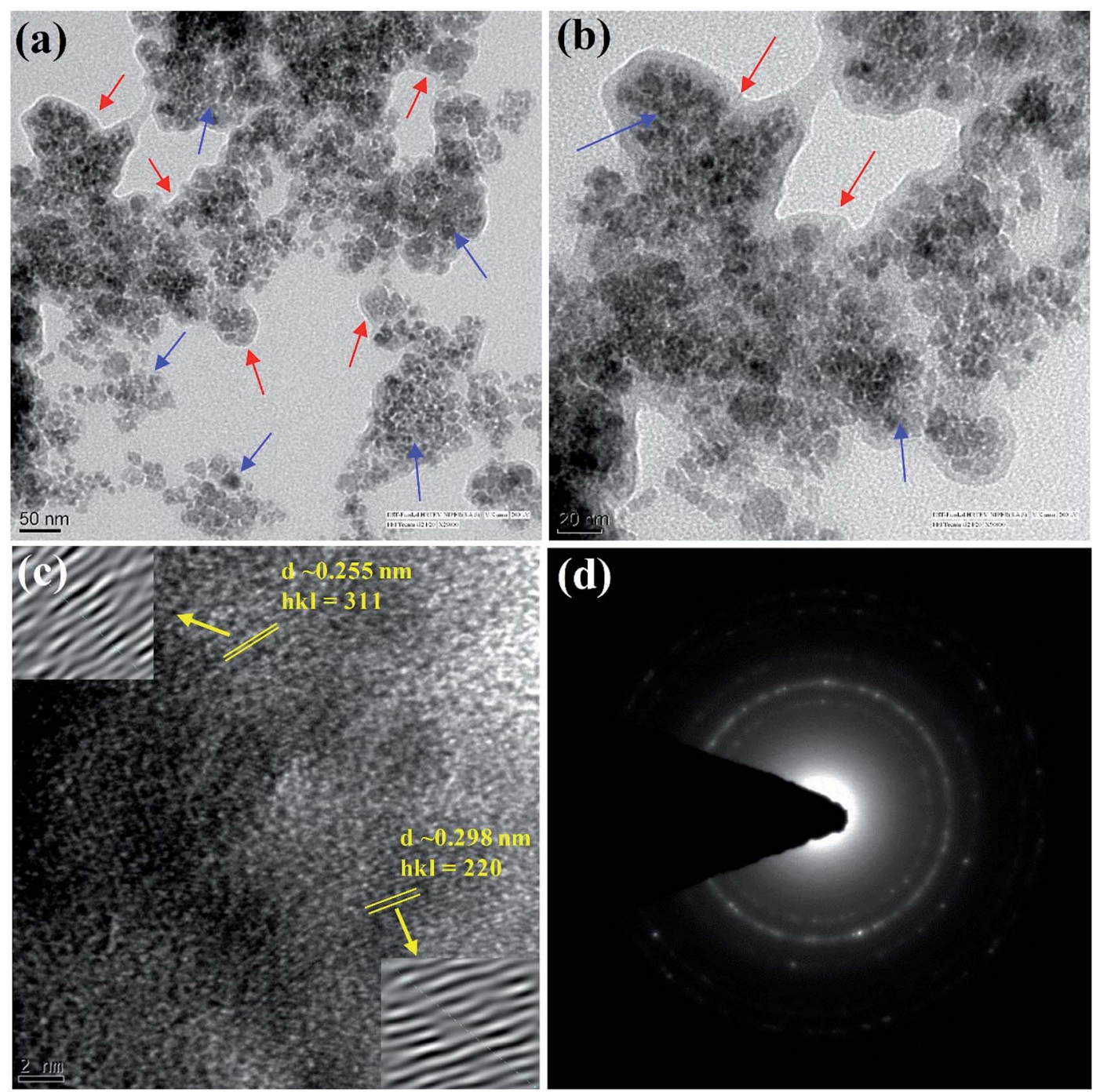

Fig. 2 (a and b) HR-TEM images, (c) lattice fringes and (d) SAED pattern of Alg/Fe $\mathrm{O}_{4}$ nanoparticles. (Red arrows indicate alginate capping; blue arrows correspond to $\mathrm{Fe}_{3} \mathrm{O}_{4}$ nanoparticles). 
be $155.8 \mathrm{~nm} .{ }^{\mathbf{5 0}}$ Hence, our size was less than the previously reported. For TEM analysis, air-dried samples are used; hence actual dried size is obtained. This accounts for the difference in sizes measured by TEM and DLS. Further, to ensure the stability of nanoparticle dispersion, surface charges were recorded from the zeta potential findings. Theoretically, zeta potential is the potential distinction between the stationary layer of fluid attached to the isolated particle and dispersion medium. The zeta potential of $\mathrm{Alg} / \mathrm{Fe}_{3} \mathrm{O}_{4} \mathrm{NPs}$ was found to be around $-39.8 \mathrm{mV}$. This higher value of zeta potential indicated good stability of the synthesized nanoparticle dispersion. The stabilization was not only due to electrostatic repulsion but due to several hydroxyl and carboxylic functional groups of alginate covering the $\mathrm{Fe}_{3} \mathrm{O}_{4}$ nanoparticle surface. ${ }^{51}$

After the successful formation and characterization of Alg/ $\mathrm{Fe}_{3} \mathrm{O}_{4}$ nanoparticles, they were entrapped inside the Alg hydrogel beads and thereafter surface functionalised with PDA. Fig. 3(a-c) shows the digital photographs of freshly prepared $\mathrm{K} 1, \mathrm{~K} 2$, and $\mathrm{K} 3$ beads. As evident, the beads were spherical in shape. The prepared $\mathrm{K} 1$ beads were transparent in appearance, upon $\mathrm{Alg} / \mathrm{Fe}_{3} \mathrm{O}_{4}$ nanoparticle inclusion the beads turned brown in colour (K2) and ultimately deep black after PDA surface functionalisation. These beads were then freezedried slowly to be used for experiments (Fig. 3(d)). They were then evaluated for their attraction towards external magnet. Fig. 3(e and f) shows the strong magnetic pull of K2 and K3 beads towards wall under magnetic exposure, while magnetism was obviously absent in K1 beads. This simple visual demonstration ensured that the magnetic features of Alg/ $\mathrm{Fe}_{3} \mathrm{O}_{4}$ nanoparticles retained even after entrapment in the polymeric matrices.

The magnetic properties of $\mathrm{K} 2$ and $\mathrm{K} 3$ beads were then experimentally tested with VSM. Fig. S2† shows the magnetization curves of $\mathrm{K} 2$ and $\mathrm{K} 3$ beads with varying magnetic field at 5 and $300 \mathrm{~K}$. As expected, the beads displayed superparamagnetic behaviour with nearly zero $M_{\mathrm{r}}$ and $H_{\mathrm{c}}$ as seen for $\mathrm{Alg} / \mathrm{Fe}_{3} \mathrm{O}_{4}$ nanoparticles. However, the $M_{\mathrm{S}}$ values decreased to 3.391 and 3.158 emu $^{-1}$, for $\mathrm{K} 2$ beads at 5 and $300 \mathrm{~K}$, respectively. This can be ascribed to the presence of thick nonmagnetic polymeric shell of alginate covering the magnetic nanoparticle surface. ${ }^{52,53}$ For K3 beads, the $M_{\mathrm{s}}$ values however were found to slightly increase to 4.315 and $3.602 \mathrm{emu} \mathrm{g}^{-1}$ at 5 and $300 \mathrm{~K}$, respectively. This can be ascribed to the surface functionalization of magnetic beads with PDA that may potentially alter the magnetization of $\mathrm{Fe}_{3} \mathrm{O}_{4}$ nanoparticles. Although with comparatively low $M_{\mathrm{s}}$, still $\mathrm{K} 2$ and $\mathrm{K} 3$ beads demonstrated satisfactory ability to get attracted to an external magnet which can facilitate their removal after their antibacterial action. ${ }^{23,25}$ The $H_{\mathrm{c}}$ and $M_{\mathrm{r}}$ values of $\mathrm{K} 2$ and $\mathrm{K} 3$ beads at 5 and $300 \mathrm{~K}$ are shown in Table 2.

The morphology and composition of the freeze-dried beads was viewed under FE-SEM. Fig. 4(a1 and b1) shows that the (a)

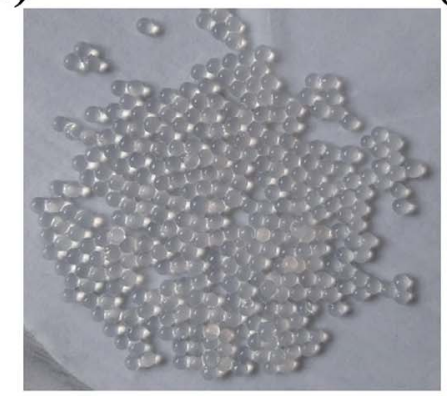

(d)

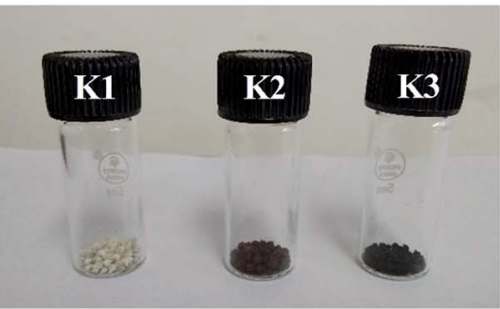

(f)

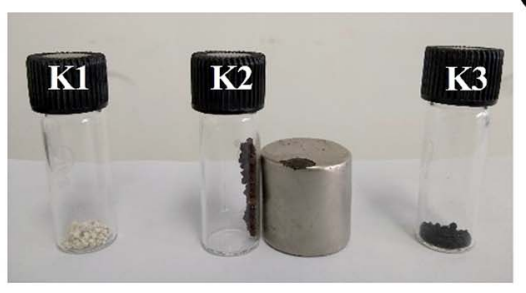

(c)
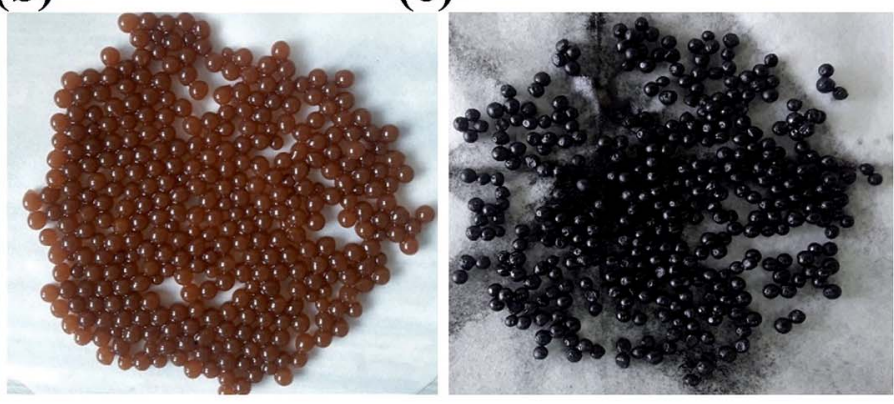

(e)

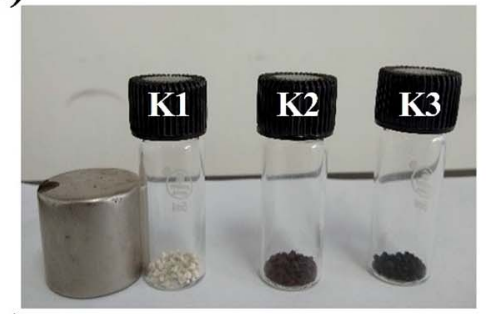

(g)

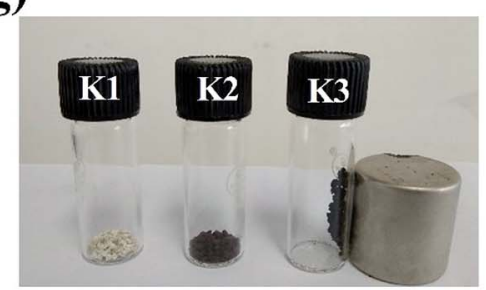

Fig. 3 Digital photographs of freshly prepared (a) K1, (b) K2, and (c) K3 beads. (d-g) Freeze-dried beads under influence of a strong magnet. 
Table 2 Magnetic parameters calculated from the VSM data of K2 and K3 beads at 5 and $300 \mathrm{~K}$

\begin{tabular}{|c|c|c|c|c|}
\hline Material & $\begin{array}{l}\text { Temperature } \\
(\mathrm{K})\end{array}$ & Saturation magnetization $\left(M_{\mathrm{s}}\right)\left(\mathrm{emu} \mathrm{g}^{-1}\right)$ & $\begin{array}{l}\text { Coercivity }\left(H_{\mathrm{s}}\right) \\
\text { (tesla) }\end{array}$ & Permanent magnetization $\left(M_{\mathrm{r}}\right)\left(\mathrm{emu} \mathrm{g}^{-1}\right)$ \\
\hline \multirow[t]{2}{*}{$\mathrm{K} 2$ beads } & 5 & 3.391 & 0.02377 & 0.46839 \\
\hline & 300 & 3.158 & 0.00435 & 0.03588 \\
\hline \multirow[t]{2}{*}{ K3 beads } & 5 & 4.315 & 0.02761 & 0.80530 \\
\hline & 300 & 3.602 & 0.00370 & 0.06078 \\
\hline
\end{tabular}

intact dried $\mathrm{K} 1$ and $\mathrm{K} 2$ beads displayed a near-spherical morphology with several wrinkles on surface probably caused by partial collapse of alginate network during dehydration process. ${ }^{24}$ On the contrary, K3 beads were also spherical but demonstrated relatively uniform surface (Fig. 4(c1). At higher magnifications, K1 beads showed typical morphology of mesoporous materials with several crests and troughs (Fig. 4(a2 and a3). ${ }^{54}$ The panoramic FE-SEM view of K2 beads showed that after addition of $\mathrm{Alg} / \mathrm{Fe}_{3} \mathrm{O}_{4}$ nanoparticles in the network, significant changes in the porosity and surface morphology were discerned (Fig. 4(b2 and b3). The surface appeared much smoother than native alginate beads. Subsequently, surface of K3 beads after PDA coating exhibited morphology considerably different, and was covered with granules (Fig. 4(c2 and c3). Our obtained FESEM findings of PDA coatings were similar to rough PDA (rPDA) coated glass substrates synthesized by Su et al. ${ }^{38}$ For a clear view of the internal structure, the freeze-dried beads were cross-sectioned using a sharp blade and then viewed. Fig. 5(a1, b1 and c1) shows the top-view of the cut K1, K2 and K3 beads, respectively. At higher magnifications, all the three beads presented a porous hydrogel structure (Fig. 5(a2, a3, b2, b3 c2 and c3)). The presence of $\mathrm{Alg} / \mathrm{Fe}_{3} \mathrm{O}_{4}$ nanoparticles entrapped inside the alginate network is evident in the cut $\mathrm{K} 2$ and $\mathrm{K} 3$ beads and is indicated by yellow arrows. Their presence was further validated by the EDS spectra displaying peaks corresponding to $\mathrm{Fe}$, O elements (Fig. 5(b4 and $\mathrm{c} 4)$ ) which were absent in K1 bead EDS (Fig. 5(a4).

The formation of beads and their structural characteristics was further understood by XRD analysis. Fig. S3a $\uparrow$ shows the XRD patterns of K1, K2 and K3 beads. Broad hump peak at $2 \theta$ $\sim 30^{\circ}$ was observed for $\mathrm{K} 1$, corresponding to the amorphous sodium alginate cross-linked with divalent $\mathrm{Ca}$. Upon $\mathrm{Alg} / \mathrm{Fe}_{3} \mathrm{O}_{4}$ nanoparticle inclusion, peak reflections corresponding to (220), (311), (511) and (440) planes were seen. After PDA functionalization, the amorphous hump was observed but the peaks corresponding to $\mathrm{Alg} / \mathrm{Fe}_{3} \mathrm{O}_{4}$ nanoparticles were not much visible. This could be assigned to inherent amorphous crystallinity of PDA. $^{46,55}$ The prepared K1, K2 and K3 bead samples were then subjected to FT-IR measurements. In the spectrum of K1 (Fig. S3b†), peaks at 1635 and $1419 \mathrm{~cm}^{-1}$, are ascribed to
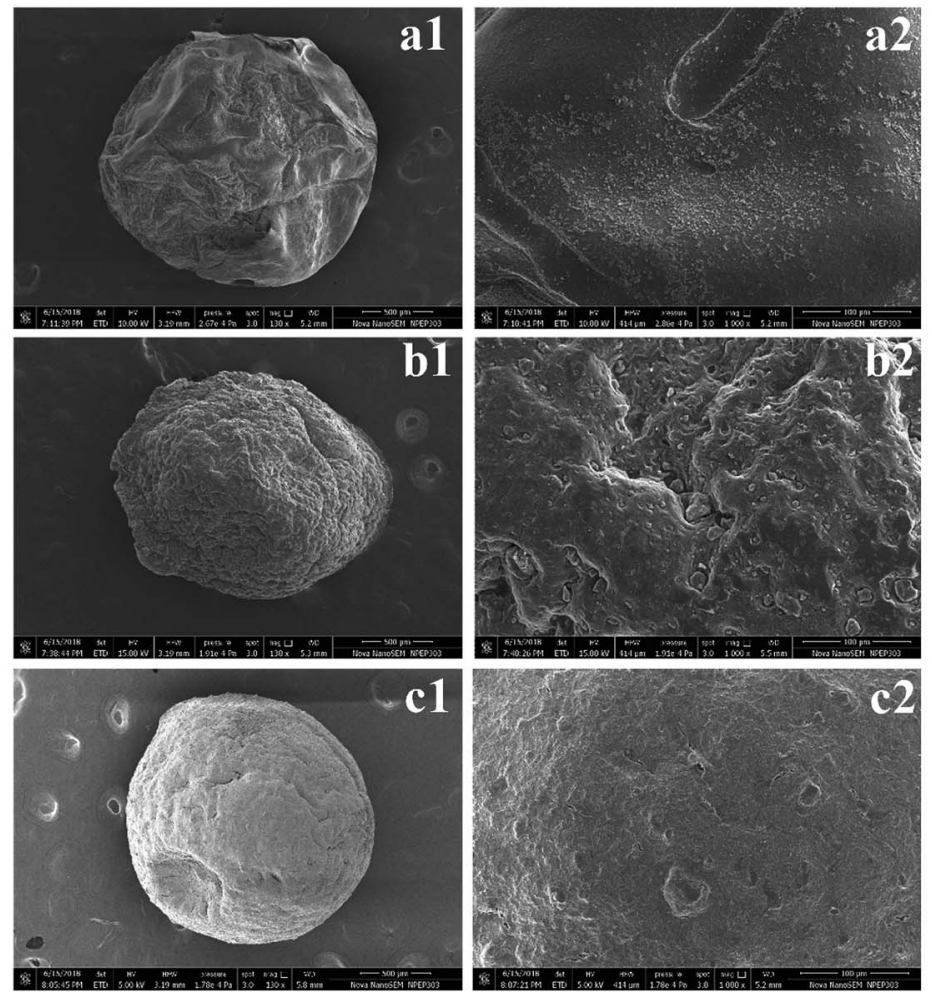

c2

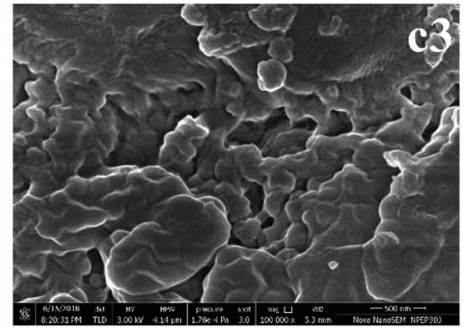

Fig. 4 FE-SEM images of freeze-dried K1, K2, and K3 beads at different magnifications. 
asymmetric and symmetric $\mathrm{COO}^{-}$stretching vibrations, respectively. Intense peak at $3429 \mathrm{~cm}^{-1}$ corresponds to $-\mathrm{OH}$ stretch. Peaks around $2920 \mathrm{~cm}^{-1}$ are for $\mathrm{C}-\mathrm{H}$ stretching. Peak at $1030 \mathrm{~cm}^{-1}$ correspond to $\mathrm{C}-\mathrm{O}-\mathrm{C}$ stretching vibration of alginate and peak at $817 \mathrm{~cm}^{-1}$ is of $\mathrm{C}-\mathrm{O}$ bending vibrations. ${ }^{20}$ In the $\mathrm{K} 2$ spectrum, all these peaks were present but the peak at $3429 \mathrm{~cm}^{-1}$ got broadened and the intensity of peak got slightly reduced. Peaks related to $\mathrm{Fe}_{3} \mathrm{O}_{4}$, were not very visible in the $\mathrm{K} 2$ spectrum probably due to their low weight content w.r.t alginate. In the $\mathrm{K} 3$ spectrum, certain differences were observed. After amine functionalization, the significant reduction in peaks at 1635,1419 and $1030 \mathrm{~cm}^{-1}$ indicated the successful reduction and surface functionalization of $\mathrm{K} 2$ beads.

For use as antibacterial modalities, the magnetic hydrogel beads should be stable under different $\mathrm{pH}$ conditions for their magnetic separation. ${ }^{56}$ With this perspective $\mathrm{K} 1, \mathrm{~K} 2$ and $\mathrm{K} 3$ beads were placed in acidic (pH 5.5) and basic (pH 7.4) buffer solutions and their swelling behavior was plotted as a function of time. As expected, all the three types of hydrogel beads underwent swelling with increase in time at both pH 5.5 and 7.4 (Fig. 6(a and b)). At 5.5, the maximal swelling was observed after $12 \mathrm{~h}$ for K1, K2 and K3 beads. However, K1 beads were unstable and completely dissociated into pieces after $12 \mathrm{~h}$. K2 beads also displayed some dissociation upon magnetic separation which decreased their weight and hence less swelling was observed at $24 \mathrm{~h}$. On the contrary, PDA functionalization imparted K3 beads with excellent stability with no visual signs of distortion. Similar were the observations at $\mathrm{pH}$ 7.4, whereby increase in swelling (\%) of beads was seen up to $12 \mathrm{~h}$ after which the swelling was constant. After $12 \mathrm{~h}, \mathrm{~K} 1$ beads completely dissociated and partial degradation was seen for K2 beads. This degradation can be assigned to $\mathrm{Ca}^{2+}$ ion exchange with the buffer ions. ${ }^{20,57}$ While K3 beads were stable and remained intact.

The effect of PDA coating on the wettability properties of Alg/ $\mathrm{Fe}_{3} \mathrm{O}_{4}$ bead surface was also studied. The results of water contact angle measurements of $\mathrm{K} 1, \mathrm{~K} 2$ and $\mathrm{K} 3$ beads are shown in Fig. 6(c). For K1 beads, the contact angle was observed to be $\sim 65.9^{\circ}$. Upon incorporation of $\mathrm{Alg} / \mathrm{Fe}_{3} \mathrm{O}_{4}$ nanoparticles, the contact angle decreased to $\sim 57.8^{\circ}$; making $\mathrm{K} 2$ beads more hydrophilic in nature. The plausible factor for increase in hydrophilicity of $\mathrm{K} 2$ beads could be the presence of more hydrophilic alginate content (covering $\mathrm{Fe}_{3} \mathrm{O}_{4}$ nanoparticle surface) than $\mathrm{K} 1^{58}$. After PDA coating, the contact angle further reduced to $\sim 55^{\circ}$ in case of $\mathrm{K} 3$ beads, indicating more hydrophilic surfaces. These findings are in consistence with previous studies where PDA is known to make surfaces more hydrophilic. ${ }^{38,59,60}$

Elasticity and viscosity are significant properties related to hydrogel materials. Any change in the structure will reflect a change in these properties. ${ }^{61}$ Thus, the rheological properties of hydrogel beads were studied to understand any changes. Fig. 6(d) shows variation in dynamic storage moduli $\left(\mathrm{G}^{\prime}\right)$ and loss moduli $\left(\mathrm{G}^{\prime \prime}\right)$ of $\mathrm{K} 1, \mathrm{~K} 2$ and $\mathrm{K} 3$ beads with frequency at a constant strain of $0.1 \%$ and fixed gap of $500 \mu \mathrm{m}$. $\mathrm{G}^{\prime}$ indicates elastic behavior while $\mathrm{G}^{\prime \prime}$ symbolize viscous behavior. For all three (K1, K2 and K3), $\mathrm{G}^{\prime}>\mathrm{G}^{\prime \prime}$ typical of viscoelastic solids was observed. ${ }^{62,63}$ Moreover, $\mathrm{G}^{\prime}$ was in the order $\mathrm{K} 3>\mathrm{K} 1>\mathrm{K} 2$ and increased with increase in frequency. While entrapment of $\mathrm{Fe}_{3} \mathrm{O}_{4}$ nanoparticles in $\mathrm{K} 2$ was found to mildly affect the internal cross-links of alginate chains resulting in slight $\mathrm{G}^{\prime}$
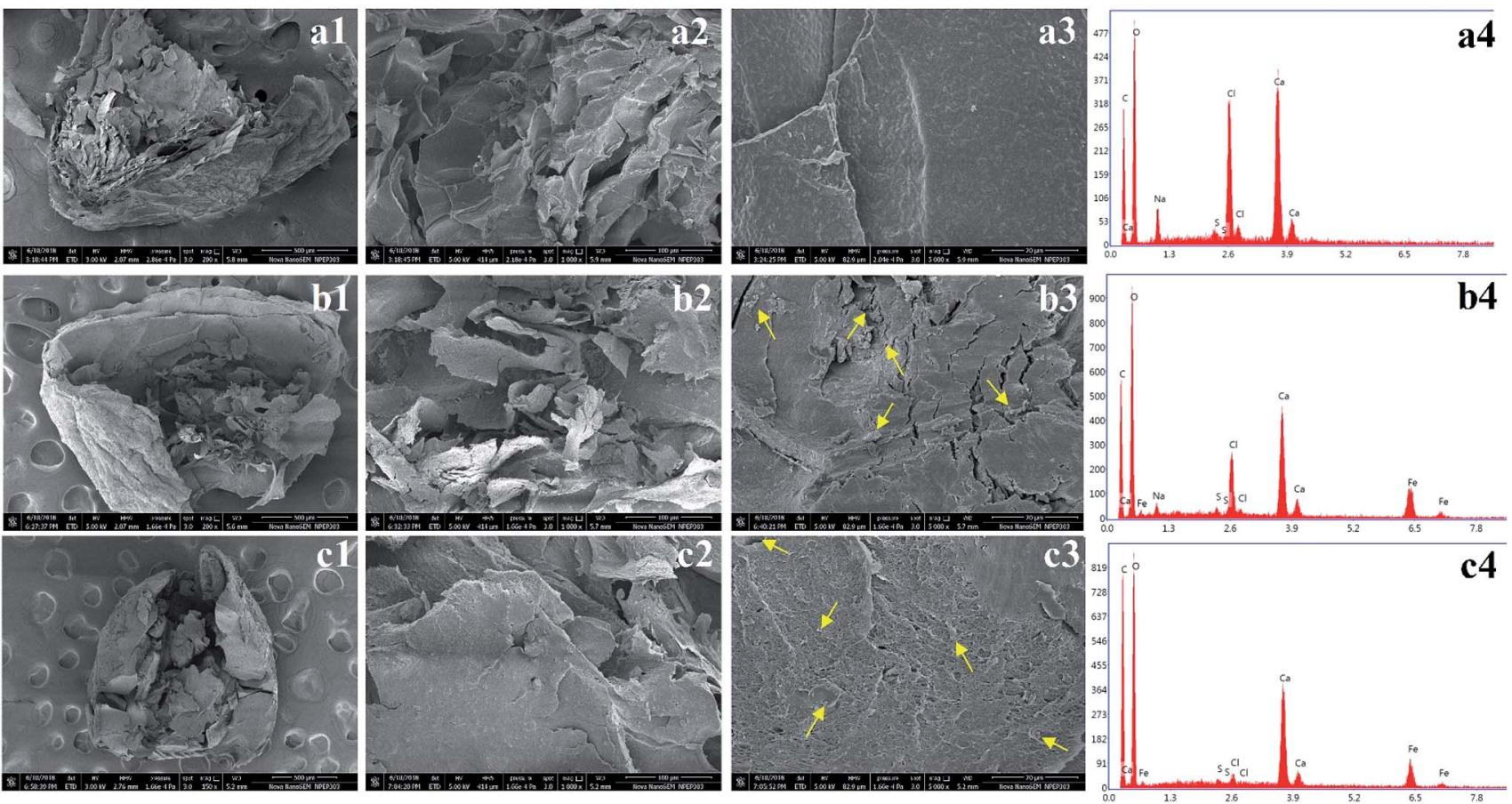

Fig. 5 FE-SEM images of cross-sectioned freeze-dried K1, K2, and K3 beads and their EDS analysis. (Yellow arrows indicate existence of Alg/ $\mathrm{Fe}_{3} \mathrm{O}_{4}$ nanoparticles). 
(a)

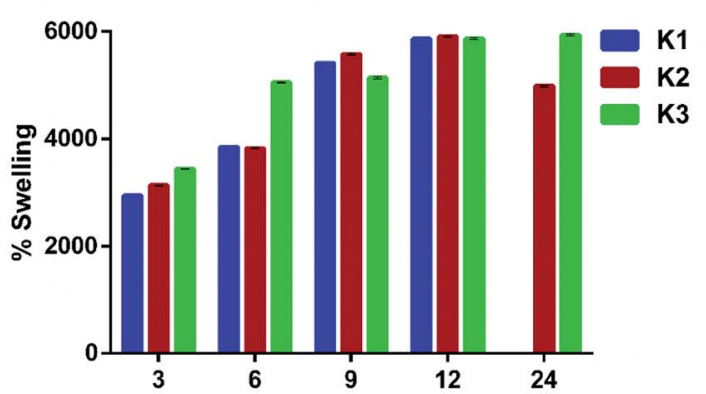

(c)

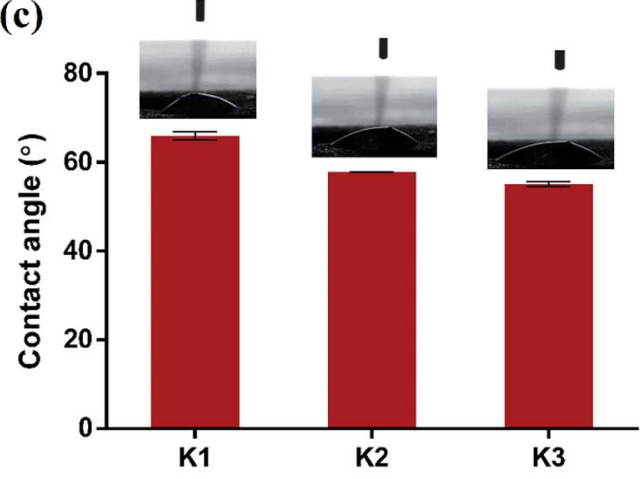

(b)

pH 7.4

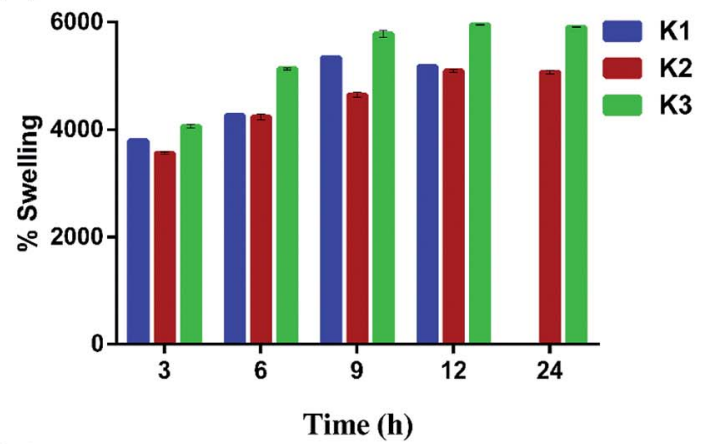

(d)

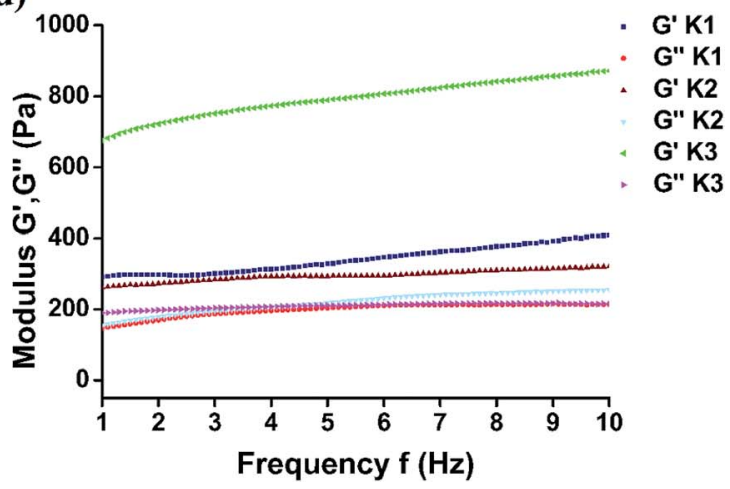

Fig. 6 (a and b) Time dependent swelling studies with variation in $\mathrm{pH}$, (c) water contact angle measurements, and (d) rheological properties of beads.

reduction than $\mathrm{K} 1$. The large $\mathrm{G}^{\prime}$ values of $\mathrm{K} 3$ obtained suggest positive influence of PDA functionalization on elasticity of beads. Next, viscometry tests were also performed. Fig. S4† shows the change in viscosity with shear rate in the log scale for $\mathrm{K} 1, \mathrm{~K} 2$ and $\mathrm{K} 3$ beads. A trend of decrease in viscosity with increase in shear rate was observed in all the cases due to pseudo-plastic or shear-thinning behavior. ${ }^{64,65}$ At low shear rates, the viscosity was in the order $\mathrm{K} 3>\mathrm{K} 2>\mathrm{K} 1$, owing to PDA surface functionalization and $\mathrm{Fe}_{3} \mathrm{O}_{4}$ nanoparticles which increased the molecular weight and hence viscosity.

\subsection{Antibacterial assessment}

The antibacterial performance of $\mathrm{K} 3$ beads was assessed against E. coli, S. typhi, S. aureus, and L. monocytogenes as bacterium models. The growth behavior of bacteria in presence of different concentrations of beads was monitored to correlate the observed bacterial density with their antibacterial efficacy. Fig. 7 shows the bacterial optical density values obtained at $600 \mathrm{~nm}$ $\left(\mathrm{OD}_{600}\right)$ after $12 \mathrm{~h}$ incubation with different concentrations of $\mathrm{K} 1, \mathrm{~K} 2$ and $\mathrm{K} 3$ beads. As seen in Fig. 7(a), a tremendous decrease in $E$. coli growth was observed with increase in K3 concentration. As less as $2 \mathrm{mg}$ of $\mathrm{K} 3$ beads was sufficient to decrease bacterial number to more than $50 \%$ compared to untreated bacteria (control). At $12 \mathrm{mg}$, the bacterial growth was minimal and almost remained unchanged upon treatment with 16 and $20 \mathrm{mg}$ beads. On the contrary, K1 beads were found to surprisingly promote $E$. coli growth with increase in concentration. While treatment with $\mathrm{K} 2$ beads did not affect the $E$. coli growth even at higher concentrations. This findings indicated that the bactericidal effect of K3 beads may chiefly be due to the existence of PDA granules on their surface. These deposited PDA granules tend to upsurge surface irregularities which favor attachment and buildup of free-swimming bacteria and promote bacterial killing. ${ }^{38,66,67}$ When tested on $S$. typhi, a significant decrease in growth was seen for K3 beads and a marginal decrease with $\mathrm{K} 2$ beads with rise in concentration compared to control (Fig. 7(b)). However, K1 beads could not inhibit $S$. typhi growth and proliferation at all concentrations. Similarly, as evident in Fig. 7(c and d) K3 beads were found to suppress $S$. aureus and L. monocytogenes growth effectively at concentrations $4 \mathrm{mg}$ and higher when compared to $\mathrm{K} 1$ and $\mathrm{K} 2$ beads.

Based on these observations, the bacterial growth kinetic experiments were also performed. Fig. $8(\mathrm{a}-\mathrm{d})$ shows the time dependent bacterial killing by K3 beads. As observed for all the four bacterial strains, with increase in time from $0-8 \mathrm{~h}$, the number of viable bacteria were reduced upon $\mathrm{K} 3$ exposure as compared to the untreated or control bacteria. After $8 \mathrm{~h}$, considerable suppression in growth was seen in $S$. typhi and $S$. aureus, and reduction in E. coli and L. monocytogenes bacterial number after K3 treatment. However, the basis for difference in bacterial response is still unclear and under investigation.

Following, to investigate in more depth the antibacterial performance of $\mathrm{K} 3$ beads, membrane integrity assay was 
(a)

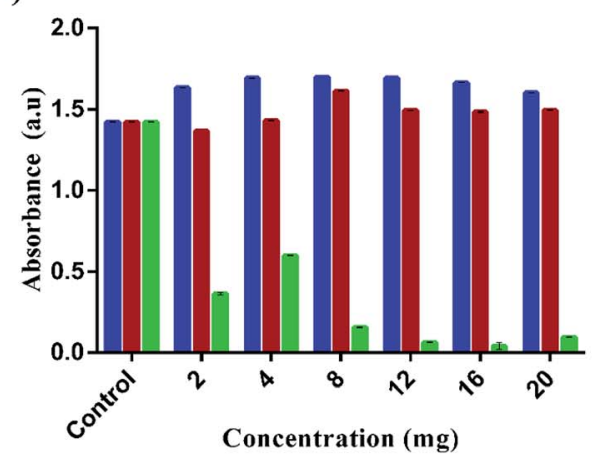

(c)

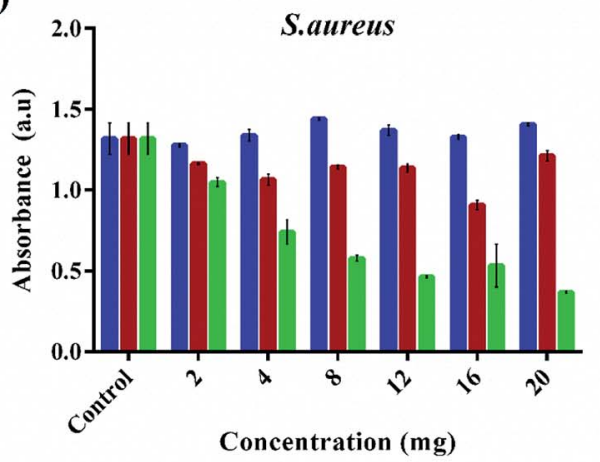

(b)
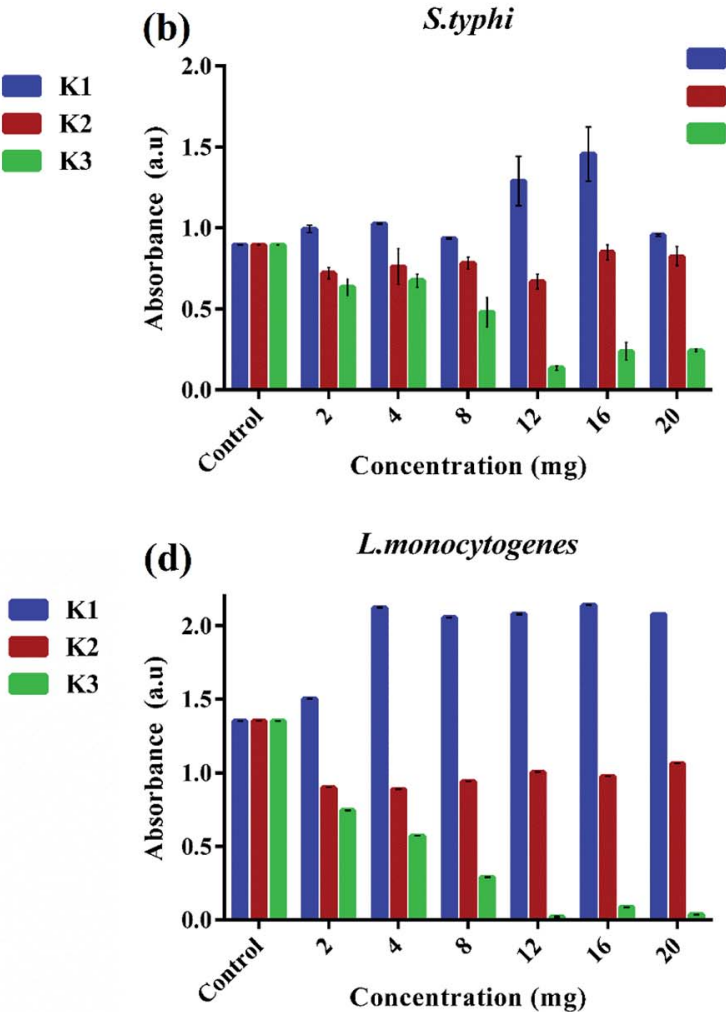

(d)

L.monocytogenes

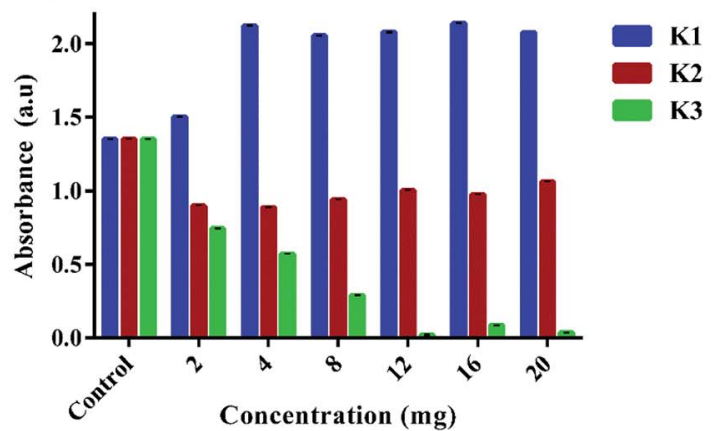

Fig. 7 Concentration dependent bacterial inhibition of K1, K2 and K3 beads after $12 \mathrm{~h}$.

(a)

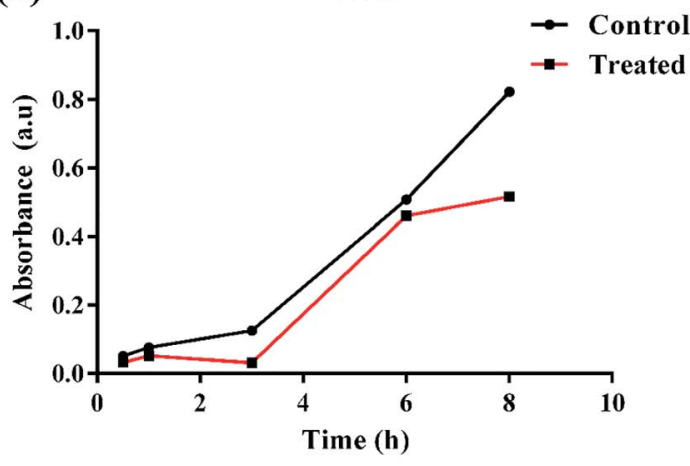

(c)

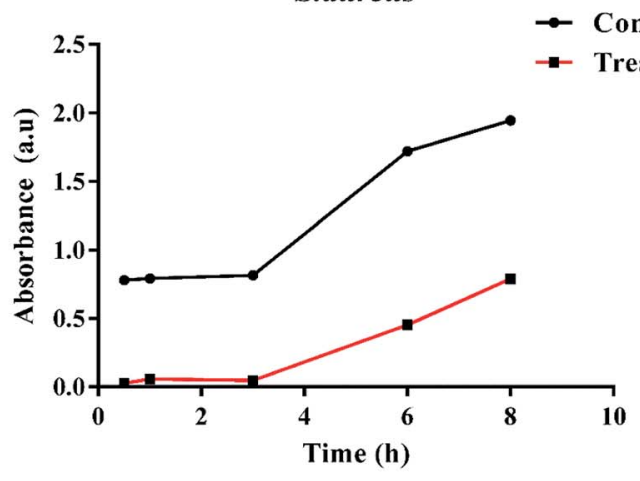

(b) S.typhi

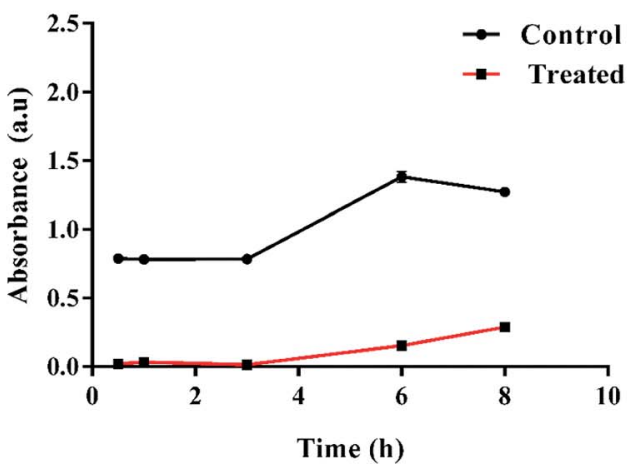

(d) L.monocytogenes

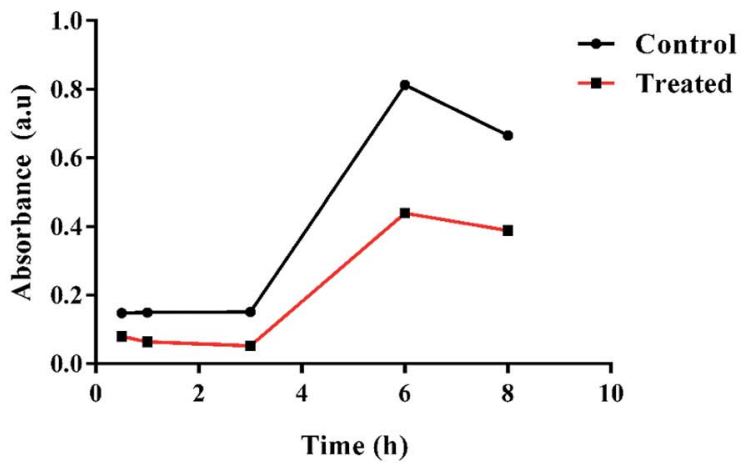

Fig. 8 Time dependent bacterial killing of K3 beads. 


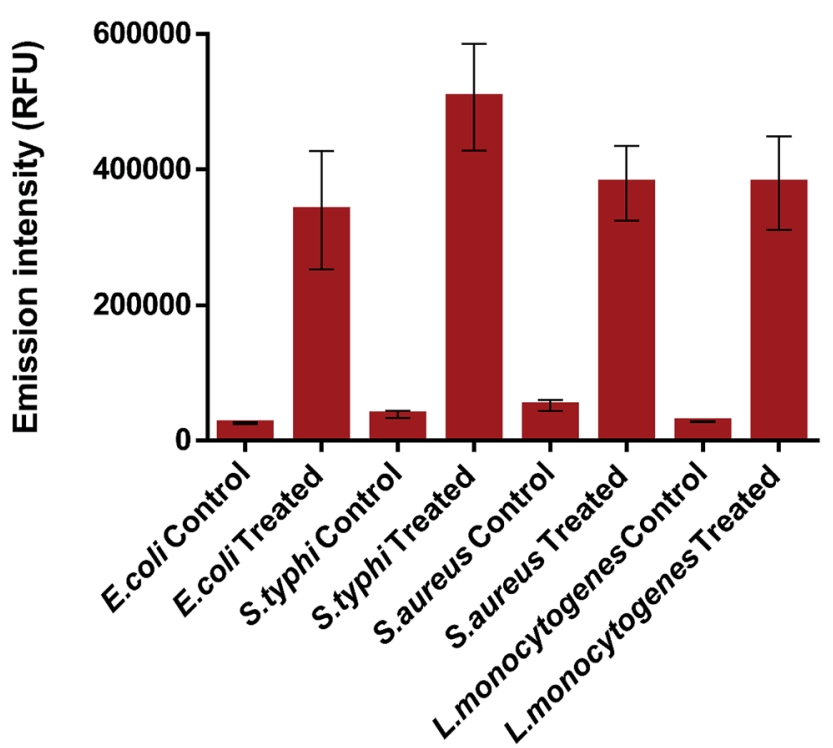

Fig. 9 Variation in fluorescence of PI for treated and control bacteria.

performed. For this, the K3 exposed bacteria were subjected to PI staining and the emission fluorescence of PI dye was recorded. PI can penetrate inside membrane compromised bacteria and not inside intact/healthy bacteria. ${ }^{6,69}$ Fig. 9 shows the variation in fluorescence intensity of PI for treated and control bacteria. As expected, all the treated bacteria demonstrated significantly high uptake of PI stain than the control ones. The little fluorescence seen in case of control or untreated bacteria could be due to autofluorescence or slight membrane damage during sample preparation. Around 3.6 times increase in PI intensity was observed for K3 treated E. coli (Fig. S5†). While, $\sim 2.0,8.1$ and 2.1 times increase was observed for treated $S$. typhi, S. aureus and L. monocytogenes bacteria, respectively. The observed results clearly indicate that loss of membrane integrity occurs upon exposure to K3 beads, which eventually results in bacterial death.

Subsequently, the reusability of magnetic K3 beads to inhibit the bacterial growth was studied for four consecutive cycles. Fig. 10(a-d) shows the percent inhibition in E. coli, S. typhi, S. aureus, and L. monocytogenes upon K3 exposure for $12 \mathrm{~h}$. The obtained results revealed that $\mathrm{K} 3$ beads were able to suppress all bacteria effectively for 3 cycles ( $>50 \%$ inhibition). After $4^{\text {th }}$ cycle, the beads could inhibit the bacterial growth, but the percent inhibition was reduced compared to cycle 1 . This could plausibly be due to partial degradation of $\mathrm{K} 3$ beads under repeated shaking conditions and PBS washings. Nevertheless, the beads could be used for around 3 repeated cycles of antibacterial experiments. In totality, all findings highlight the superior ability of $\mathrm{K} 3$ beads to resist bacterial growth than $\mathrm{K} 1$ and $\mathrm{K} 2$ beads and can serve as promising reusable antibacterial materials. (a)
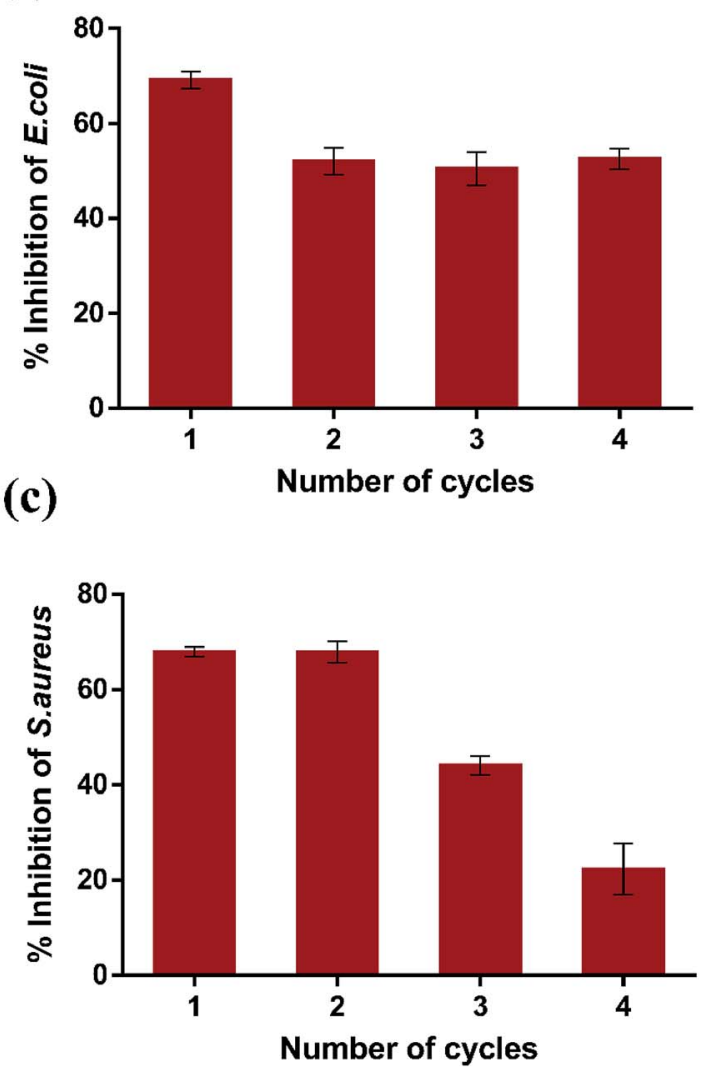

(b)

(d)
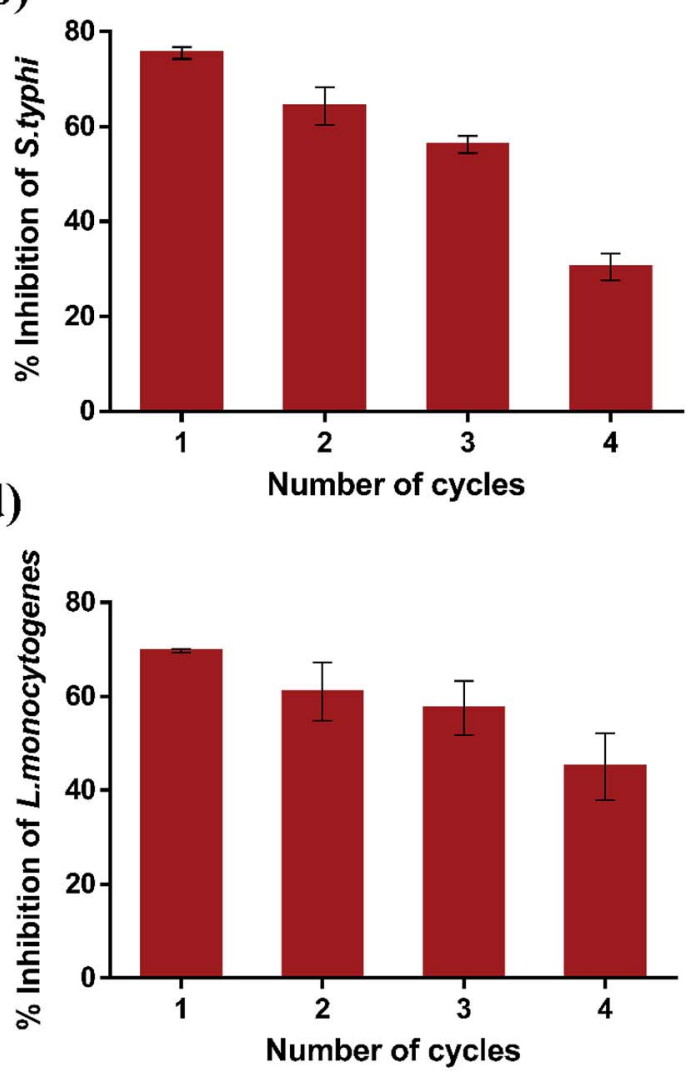

Fig. 10 Reusability of K3 beads. 


\section{Conclusions}

In the present work, we have prepared magnetically active PDA/ $\mathrm{Alg} / \mathrm{Fe}_{3} \mathrm{O}_{4}$ porous matrices in bead form (K3) adopting a stepwise strategy to assess their antibacterial competence. Alg/ $\mathrm{Fe}_{3} \mathrm{O}_{4}$ nanoparticles, $\sim 8 \mathrm{~nm}$ in size were synthesized by chemical co-precipitation and entrapped inside Alg hydrogel to impart magnetic abilities. The PDA granules were homogenously deposited on the K3 surface as observed under FE-SEM. Even after PDA functionalization, K3 beads demonstrated superparamagnetic property and fast magnetic response. Swelling and water-wettability studies revealed that PDA enhanced their stability in different $\mathrm{pH}$ and hydrophilicity to a great extent. Rheological studies suggested enhanced elastic behavior and viscosity of K3. A series of conducted experiments validated strong antibacterial performance of $\mathrm{K} 3$ beads against E. coli, S. typhi, S. aureus, and L. monocytogenes bacterial strains at low concentrations. We believe that these functionalized hydrogel beads could be used efficaciously as magneticallycontrolled reusable antibacterial agents.

\section{Conflicts of interest}

There are no conflicts to declare.

\section{Acknowledgements}

Ishita Matai would like to thank Department of Science and Technology [DST/INSPIRE/04/2016/002181], India for providing the financial support. Authors also thank ICON Analytical Ltd. For helping with FE-SEM experiments. Sincere acknowledgement to CSIR-CSIO, Chandigarh for providing the necessary laboratory and analytical facilities.

\section{References}

1 WHO and UNICEF, Progress on Drinking Water, Sanitation and Hygiene Update and SDG Baselines, 2017.

2 S. F. O. R. Water, Nature-Based Solutions for Water Wwdr 2018 Solutions for Water, 2018.

3 J. P. S. Cabral, Int. J. Environ. Res. Public Health, 2010, 7, 3657-3703.

4 P. K. Pandey, P. H. Kass, M. L. Soupir, S. Biswas and V. P. Singh, AMB Express, 2014, 4, 1-16.

5 A. Mahapatra, N. Padhi, D. Mahapatra, M. Bhatt, D. Sahoo, S. Jena, D. Dash and N. Chayani, J. Clin. Diagn. Res., 2015, 9, DC09-DC11.

6 A. Rożej, A. Cydzik-Kwiatkowska, B. Kowalska and D. Kowalski, World J. Microbiol. Biotechnol., 2015, 31, 37-47.

7 F. Ramírez-Castillo, A. Loera-Muro, M. Jacques, P. Garneau, F. Avelar-González, J. Harel and A. Guerrero-Barrera, Pathogens, 2015, 4, 307-334.

8 X. Zhao, F. Zhao, J. Wang and N. Zhong, RSC Adv., 2017, 7, 36670-36683.

9 D. Berry, C. Xi and L. Raskin, Curr. Opin. Biotechnol., 2006, 17, 297-302.
10 G. E. Murray, R. S. Robin, B. Junkins and D. J. Kushner, Appl. Environ. Microbiol., 1984, 48, 73-77.

11 H. Farkas-Himsley, Appl. Environ. Microbiol., 1964, 12, 1-6.

12 A. K. Gupta and M. Gupta, Biomaterials, 2005, 26, 3995-4021.

13 A. M. Gutierrez, T. D. Dziubla and J. Z. Hilt, Rev. Environ. Health, 2018, 32, 111-117.

14 N. N. Nassar, Appl. Adsorbents Water Pollut. Control, 2012, pp. 81-118.

15 P. N. Dave and L. V. Chopda, J. Nanotechnol., 2014, 2014, 398569.

16 R. Lakshmanan, C. Okoli, M. Boutonnet, S. Järås and G. K. Rajarao, Bioresour. Technol., 2013, 129, 612-615.

17 K. Y. Lee and D. J. Mooney, Prog. Polym. Sci., 2012, 37, 106126.

18 M. Rinaudo, Tip, 2014, 17, 92-96.

19 S. Reakasame and A. R. Boccaccini, Biomacromolecules, 2018, 19, 3-21.

20 I. Matai and P. Gopinath, ACS Biomater. Sci. Eng., 2016, 2, 213-223.

21 Ý. A. Mørch, I. Donati, B. L. Strand and G. Skjåk-Bræk, Biomacromolecules, 2006, 7, 1471-1480.

22 K. L. Chen, S. E. Mylon and M. Elimelech, Langmuir, 2007, 23, 5920-5928.

23 F. Q. Wang, P. Li, J. P. Zhang, A. Q. Wang and Q. Wei, Pharm. Dev. Technol., 2011, 16, 228-236.

24 X. Meng, P. Li, Q. Wei and H. X. Zhang, Pharm. Dev. Technol., 2011, 16, 22-28.

25 L. L. Zhang, P. Li, Y. M. Li and A. Q. Wang, Drug Dev. Ind. Pharm., 2012, 38, 872-882.

26 X. Wang, Z. Jiang, J. Shi, C. Zhang, W. Zhang and H. Wu, Ind. Eng. Chem. Res., 2013, 52, 14828-14836.

27 S. Kondaveeti, D. R. Cornejo and D. F. S. Petri, Colloids Surf., $B, 2016,138,94-101$.

28 R. Thaya, B. Vaseeharan, J. Sivakamavalli, A. Iswarya, M. Govindarajan, N. S. Alharbi, S. Kadaikunnan, M. N. Alanbr, J. M. Khaled and G. Benelli, Microb. Pathog., 2018, 114, 17-24.

29 M. R. El-Aassar and X. Mo, Adv. Polym. Technol., 2016, 35, 298-306.

30 M. K. Zahran, H. B. Ahmed and M. H. El-Rafie, Carbohydr. Polym., 2014, 108, 145-152.

31 I. Madzovska-Malagurski, M. Vukasinovic-Sekulic, D. Kostic and S. Levic, Biomed. Mater., 2016, 11, 35015.

32 T. S. Sileika, H. Do Kim, P. Maniak and P. B. Messersmith, ACS Appl. Mater. Interfaces, 2011, 3, 4602-4610.

33 H. Lee, B. P. Lee and P. B. Messersmith, Nature, 2007, 448, 338-341.

34 S. H. Ku, J. S. Lee and C. B. Park, Langmuir, 2010, 26, 1510415108.

35 Y. Xie, B. Yan, H. Xu, J. Chen, Q. Liu, Y. Deng and H. Zeng, ACS Appl. Mater. Interfaces, 2014, 6, 8845-8852.

36 X. Chen, Y. Huang, G. Yang, J. Li, T. Wang, O. H. Schulz and L. K. Jennings, Curr. Pharm. Des., 2015, 21, 4262-4275.

37 S. Liu, J. Fu, M. Wang, Y. Yan, Q. Xin, L. Cai and Q. Xu, J. Colloid Interface Sci., 2016, 469, 69-77.

38 L. Su, Y. Yu, Y. Zhao, F. Liang and X. Zhang, Sci. Rep., 2016, 6, 1-8. 
39 R. Mrówczyński, ACS Appl. Mater. Interfaces, 2018, 10, 75417561.

40 K. Petcharoen and A. Sirivat, Mater. Sci. Eng., B, 2012, 177, 421-427.

41 I. Matai, A. Sachdev, P. Dubey, S. Uday Kumar, B. Bhushan and P. Gopinath, Colloids Surf., B, 2014, 115, 359-367.

42 P. Dubey and P. Gopinath, RSC Adv., 2016, 6, 69103-69116.

43 I. Ocsoy, M. Temiz, C. Celik, B. Altinsoy, V. Yilmaz and F. Duman, J. Mol. Liq., 2017, 227, 147-152.

44 W. Wu, Q. He and C. Jiang, Nanoscale Res. Lett., 2008, 3, 397415.

45 S. Tawab Shah, W. A. Yehye, O. Saad, K. Simarani, Z. Zaman Chowdhury, A. A. Alhadi and L. A. Al-Ani, Nanomaterials, 2017, 7, 306.

46 M. Zhang, X. He, L. Chen and Y. Zhang, J. Mater. Chem., 2010, 20, 10696-10704.

47 S. H. Liao, C. H. Liu, B. P. Bastakoti, N. Suzuki, Y. Chang, Y. Yamauchi, F. H. Lin and K. C. W. Wu, Int. J. Nanomed., 2015, 10, 3315-3328.

48 N. Bhattarai, J. Gunn and M. Zhang, Adv. Drug Delivery Rev., 2010, 62, 83-99.

49 H. li Ma, X. rong Qi, Y. Maitani and T. Nagai, Int. J. Pharm., 2007, 333, 177-186.

50 P. M. Bedê, M. H. P. da Silva, A. B.-H. da S. Figueiredo and P. V. Finotelli, Polimeros, 2017, 27, 267-272.

51 X. Zhao, Z. Li, Y. Deng, Z. Zhao, X. Li and Y. Xia, Materials, 2017, 10, 557.

52 Y. Zhang, Q. Xu, S. Zhang, J. Liu, J. Zhou, H. Xu, H. Xiao and J. Li, Sep. Purif. Technol., 2013, 116, 391-397.

53 Y. Lin, H. Chen, K. Lin, B. Chen and C. Chiou, J. Environ. Sci., 2011, 23, 44-50.

54 G. A. Naikoo, R. A. Dar and F. Khan, J. Mater. Chem. A, 2014, 2, 11792-11798.
55 G. Jiang, T. Jiang, Y. Wang, X. Du, Z. Wei and H. Zhou, RSC Adv. , 2014, 4, 33658-33661.

56 S. S. Leong, S. P. Yeap and J. K. Lim, Interface Focus, 2016, 6, 20160048.

57 G. Pasparakis and N. Bouropoulos, Int. J. Pharm., 2006, 323, 34-42.

58 I. Zgura, T. Beica, I. L. Mitrofan, C. G. Mateias, D. Pirvu and I. Patrascu, Dig. J. Nanomater. Biostruct., 2010, 5, 749-755.

59 J.-H. Jiang, L.-P. Zhu, X.-L. Li, Y.-Y. Xu and B.-K. Zhu, J. Membr. Sci., 2010, 364, 194-202.

$60 \mathrm{~J}$. T. Arena, B. McCloskey, B. D. Freeman and J. R. McCutcheon, J. Membr. Sci., 2011, 375, 55-62.

61 I. Fernández Farrés and I. T. Norton, Food Hydrocolloids, 2014, 40, 76-84.

62 B. E. Larsen, J. Bjørnstad, E. O. Pettersen, H. H. Tønnesen and J. E. Melvik, BMC Biotechnol, 2015, 15, 1-12.

$63 \mathrm{H}$. Li, S. Liu and L. Lin, Int. J. Bioprint., 2016, 2, 10-12.

64 J. Malda, J. Visser, F. P. Melchels, T. Jüngst, W. E. Hennink, W. J. A. Dhert, J. Groll and D. W. Hutmacher, Adv. Mater., 2013, 25, 5011-5028.

65 P. Duan, N. Kandemir, J. Wang and J. Chen, MRS Adv., 2017, 2, 1309-1314.

66 M. Quirynen, H. C. Van Der Mei, C. M. L. Bollen, A. Schotte, M. Marechal, G. I. Doornbusch, I. Naert, H. J. Busscher and D. Van Steenberghe, J. Dent. Res., 1993, 72, 1304-1309.

67 C. Luo, W. Liu, B. Luo, J. Tian, W. Wen, M. Liu and C. Zhou, Carbohydr. Polym., 2017, 156, 235-243.

68 M. E. Weeks, G. Nebe von Caron, D. C. James, C. M. Smales and G. K. Robinson, J. Microbiol. Methods, 2006, 66, 43-55.

69 H. Sträuber and S. Müller, Cytometry, Part A, 2010, 77, 623634. 